Dr. Rasha Mohamed Wagdy M. Elleithy

\title{
Bearing the Burden to Neverland: Exorcising Demons of Otherness with Healing Incantations of Magical Realism in Leslie Marmon Silko's Ceremony, Gloria Naylor's Bailey's Café and Laura Esquivel's Like Water for Chocolate.
}

\author{
Dr. Rasha Mohamed Wagdy M. Elleithy
}

\begin{abstract}
In three works that span a panorama of American heritage and culture, three ethnic women writers carry their burden of subjugation, repression and pain to Neverland through storytelling as well. This Neverland is a distant imaginative magical land in which stories of abuse and accounts of oppression turn into narratives of power and healing in which our women writers Leslie Marmon Silko, Gloria Naylor and Laura Esquivel do not narrate their texts, but rather serve them to the reader as a delicious meal. They do this through a mixture of food recipes, magical banquets and metaphysical ceremonies. With their Magical Realist narratives, the three writers present their readers with three delicious banquets of harsh reality with a sprinkle of magic. Their meals are beautifully served as only a crafty enchantress could do to entertain her dinner guests. With their well-measured touch of magic, the reader is taken in a fantastic experience. In their narratives, the effect of vibrant magic within their realist narratives vary: sometimes they use it to ease the pain of horrific experiences, other times they spark hope in an otherwise hopeless condition, or they simply manage to engage the reader in a process of Aristotelian catharsis that arises pleasure, entertainment and pain. And similar to Shahrazad's feminine defensive technique, they attempt to fight otherness they had personally and professionally fell victim of through what women have always resorted to: imagination and storytelling. In the three novels, storytelling is combined with magic in a feminist approach employing the technique of Magical Realism. This paper is divided into two parts. The first part is devoted to a quick exploration of Feminism-with special emphasis on ethnic Feminism--and Magical Realism and their historical implications. This will be explored within the American milieu in which ethnicity is of a special nature. The second part will be devoted to the study of the selected works of the three writers in order to apply the basic elements of Ethnic Magical Feminism on these works concluding with the common experience, pain and hope expressed in these works.
\end{abstract}

Keywords: Magical Realism- Feminism- Otherness- Ethnicity- Magical Feminism 
Bearing the Burden to Neverland: Exorcising Demons of Otherness with Healing Incantations of Magical Realism in Leslie Marmon Silko's Ceremony, Gloria Naylor's Bailey's Café and Laura Esquivel's Like Water for Chocolate.

For a thousand and one nights, Shahrazad enchanted her killer king with her fascinating stories. Day after day and night after night, through her imaginative tales of princes and princesses, demons and sorcerers, foreign and exotic places, three-eyed creatures and beastly monsters, she was able to trade her life for her stories. A beautiful girl who was doomed to a forced marriage and a death sentence in vengeance of a presumed adultery of her husband's-Shahryar's-previous wife, she manages to escape the tragedy of her life and her sealed fate. Through storytelling, she manages to carry this burden to a land of fantasy and illusion--to Neverland. She distracts the king from killing her and also from his own tragedy as a wounded man and betrayed husband with tales of glory and defeat and stories of love, betrayal revenge and passion. Combining magic with reality, she succeeds in luring her king into keeping her alive for her immortal tale to outlive generations of threatened and afraid women, and abusive and tyrant men.

Loyal Shahrazad's disciples- women of all ages and places- still use her combination of storytelling and magic in their everyday life for entertainment, education or the manipulation of patriarchy. A mother would continuously narrate stories of magic and adventures to her kids to teach and entertain them. Women kill time chatting their boredom away with feminine gossip that combines facts, humour and petty or tragic fantasies. On the other hand, abused, defeated and batted women tell their own stories for much deeper reasons. Whether it is in a group chat, to their therapist or in written texts, they seek refuge in the act of storytelling itself. An act of freedom, of self-identification, and of courage, storytelling gives abused women a haven of reconciliation with oneself and with society. Besides, such accounts form the foundation for much of the work of feminists in their pursuit for social reform. As Janice Haaken states in her book Hard Knocks, "[W]omen who have suffered the hardest knocks under patriarchy, whether victims of rape, incest, domestic assault, sex trafficking, or war, occupy special positions in the cultural legacy of grassroots Feminism" (3). It is from those patriarchal hard knocks on feminine brains and bodies, that her book's name comes from. Story telling is, as Haaken states, placed at the center of human development

(2) and thus these stories, which she calls "subversive storytelling" (4) are the essence of any hope for social change. Stories told by women, in their own voices, concerning their own experiences 


\section{Dr. Rasha Mohamed Wagdy M. Elleithy}

are not a means of whining or moaning. They are an act of freedom and a documentation of what they have been through which becomes a central condition for identifying gender based stereotypical evils and combating misogynist biased discourses and activities.

In three works that span a panorama of American heritage and culture, three ethnic women writers carry their burden of subjugation, repression and pain to Neverland through storytelling as well. This Neverland is a distant imaginative magical land in which stories of abuse and accounts of oppression turn into narratives of power and healing in which our women writers Leslie Marmon Silko, Gloria Naylor and Laura Esquivel do not narrate their texts, but rather serve them to the reader as a delicious meal. They do this through a mixture of food recipes, magical banquets and metaphysical ceremonies. With their Magical Realist narratives, the three writers present their readers with three delicious banquets of harsh reality with a sprinkle of magic. Their meals are beautifully served as only a crafty enchantress could do to entertain her dinner guests. With their wellmeasured touch of magic, the reader is taken in a fantastic experience. In their narratives, the effect of vibrant magic within their realist narratives vary:

sometimes they use it to ease the pain of horrific experiences, other times they spark hope in an otherwise hopeless condition, or they simply manage to engage the reader in a process of Aristotelian catharsis that arises pleasure, entertainment and pain. And similar to Shahrazad's feminine defensive technique, they attempt to fight otherness they had personally and professionally fell victim of through what women have always resorted to: imagination and storytelling.

Haaken argues, based on many studies, that the mind is organized to generate coherent accounts. Emotionally arousing events are "particularly ripe for generating stories in an attempt to explain what happened, why it happened, and who was responsible” (5). However, such emotionally arousing stories do not always find receptive audiences (5). Being a psychologist, she had a long experience in the realm of 'listening' to stories that are hard to tell. According to her, she found out that people do not like to hear about bad experiences as much as it is extremely difficult for abused women to tell their stories. As she points out, it is thus difficult for the abused woman to tell her story either because "the experiences are difficult to put into words or because others are uneasy and therefore stop listening" (6). On the other hand, stories of abused women are definitely difficult to hear "and thus are vulnerable to unconscious structuring or filling in of the gaps on the part of the listener" (6). The difficulty of the experience, humiliation of speaking about it, and the pain of the experience led 
Bearing the Burden to Neverland: Exorcising Demons of Otherness with Healing Incantations of Magical Realism in Leslie Marmon Silko's Ceremony, Gloria Naylor's Bailey's Café and Laura Esquivel's Like Water for Chocolate.

women into new directions. Instead of simply 'telling their story' with its beginning, climax and denouements, feminists created new denouements and new endings. The claim that all women were equally vulnerable to male violence, emerged as a rallying cry that challenges the seductive fantasy that women could individually negotiate their fate and find security in the arms of a good man instead of creating their own security by themselves (8). While sleeping beauty waited for the reviving kiss from a prince who would give her life and dignity back, feminists stopped looking for the good men who would replace those vile males. Instead,

"women sought refuge in their collective strength." (8) In the United States of America, for instance, "[H]undreds of crisis centers and shelters, run by and for women, were established throughout North America, Europe, and Britain." (8)

It is notable that our writers do exactly this. Instead of searching for 'good men', they assume their role as bearers of life to humanity and the most powerful instrument in the continuity of the human race. As powerful women and writers, they start telling their stories and stories of their fellow ladies and gentlemen. Their stories are the story of their gender, race and nation and as women, their narratives are not told, they are served. Modern Western Shahrazads are evoking the muses of Western mythology to combat patriarchy, stereotyping, racism, ethnicity and sexism. In one of these myths, King Tereus of Thrace who was married to Procne, daughter of Pandion I king of Athens, desires his wife's sister Philomela. In his lust for her and her reluctance, he rapes her and for fear of exposing him to her sister, he cuts out her tongue. Despite her inability to speak, Philomela weaves a tapestry that tells her story. On receiving her tapestry, Procne kills her own son by Tereus, Itys, boils him and serves him as a meal to her husband. After eating his own son, Tereus finds out what the two sisters had done for him and chases them with an axe. On praying to the gods to help them escape his anger, they are both transformed into birds. In the myth, a lustful man desired his wife's sister, raped her and cut her tongue to cover up for his crime. In reality, ethnic women have been systematically raped by an androcentric patriarchal racist structure that privileges masculinity over femininity and white over colored. Like the myth, their tongues had been cut out as women and ethnic citizens, and thus they were transformed into singing birds through singing out their stories in written texts. 


\section{Dr. Rasha Mohamed Wagdy M. Elleithy}

May be they won't be able to document their story through facts narration, but they would definitely sing their coded hymn hoping it would come across a sympathizing ear.

So, like Philomena, our authors decided to weave their stories into a tapestry of magic that knits threads of love, sensuality, heritage, unity, and fulfillment with oppression, cruelty, loss, loneliness, subjugation, fear and anger. They decide to serve their meals to the readers with coded encryption in which the males will enjoy the meal like Tereus not realizing they are being served their own offspring while the whole meal is a meal of revenge, retaliation and feminine scheming. In the art of magic, exorcizing demons through making amulets and conjurations or reciting spells is one of the oldest crafts. An art that is usually preserved by the elderly women of the tribe, it is most powerful to have an incantation or a spell written and then swallowed either by the patient (Wilde 13) or by the physician (Goodrich 218) for the patient to get cured. Our writers wrote their incantations and presented them to the reader hoping for an everlasting cure for their chronic pains-both the physicians' and the patients'. Through their incantations, they explore issues of Otherness-- a very pertinent feature of the American milieu-- tying the male/ female dichotomy to a global and even universal significance with a magical touch, attempting for a cure, relief and believe in a 'happily ever after' fairytale endings for their narratives. With these narratives, they present a dream and magical reality of a phoenix rebirth from the ashes of burning discrimination, judgmental stereotyping, and cruel oppression.

In the three novels, storytelling is combined with magic in a feminist approach employing the technique of Magical Realism. This paper will be thus divided into two parts. The first part will be devoted to a quick exploration of

Feminism-with special emphasis on ethnic Feminism--and Magical Realism and their historical implications. This will be explored within the American milieu in which ethnicity is of a special nature. The three writers discussed in this paper are carefully chosen writers as they represent the three mainstreams of ethnic women writers in the United States of America. Whereas Leslie Marmon Silko is a Native American writer, Gloria Naylor is a black American and Laura Esquivel represents a whole population of Hispanics of Mexican origin, the second ethnic majority in the USA. The second part will be devoted to the study of the selected works of the three writers in order to apply the basic elements of Ethnic Magical Feminism on these works concluding with the common experience, pain and hope expressed in these works. 
Bearing the Burden to Neverland: Exorcising Demons of Otherness with Healing Incantations of Magical Realism in Leslie Marmon Silko's Ceremony, Gloria Naylor's Bailey's Café and Laura Esquivel's Like Water for Chocolate.

The term "Feminism" is believed to be of French origin and is mostly attributed to Charles Fourier in the 1830s (Goldstein 100), although there is no consensus among historians regarding this fact. (Offen 124) Moreover, European historians believe that the term "Feminism" itself barely existed before the twentieth century and that, from the time of its introduction, it was controversial. (Offen 124) Definitions of Feminism vary. Whether it is "a movement to end sexism, sexist exploitation, and oppression" (Hooks viii) or, as the dictionary defines it "a theory and/or movement concerned with advancing the position of women through such means as achievement of political, legal, or economic rights equal to those granted men" (Defining Feminism 123), it is a term that collectively refers to a body of beliefs and activities that aim to grant women some of the basic rights they are denied by society and its statute laws on basis of being "females". As Karen Offen asserts, a feminist is any person, whether a female or a male, whose ideas and actions meet three criteria: "(1) they recognize the validity of women's own interpretations of their lived experience and needs ... (2) they exhibit consciousness of, discomfort at, or even anger over institutionalized injustice (or inequity) toward women as a group by men as a group in a given society; and (3) they advocate the elimination of that injustice" (152).

It is especially significant to note that the history of Feminism can be traced back to the earliest documents of humanity in which powerful women ruled and enlightened thinkers and philosophers from around the globe called for the emancipation of the rights of women. It can be traced back even further with a study of prehistoric eras and the role of goddesses and early female figures in history. That is why there can by no means be one holistic history of Feminism that contains the wide range of participants in the evolution and development of movement that defends the rights of women as equal to men. There are scholarly treatises discussing Feminism in different eras and disciplines including Feminism in the Greek Literature: from Homer to Aristotle, Feminism in French Literature 1610- 1652; Feminist Writers of the Seventeenth Century; Feminism in

Eighteenth-Century England, and "Feminism in the French Revolution." (Offen 130) However, most historians and scholars, when referring to Feminism, refer to the Three Waves of Feminism as the formal historical evolution of Western Feminism. According to such accounts, Feminism started with calls for basic human rights for women 


\section{Dr. Rasha Mohamed Wagdy M. Elleithy}

and the equality with men in different aspects whether political, social or economic. At a time when it was widely believed that the primary and most adequate place for a woman is her house to carry out the basic tasks of a wife and mother: cooking, cleaning, taking care of the kids and her husband, the first wave of Feminism erupted in the late 1800s with the Suffragettes. The calls of the first wavers differed around the world but in the USA it concentrated on a number of rights especially the right of women to vote and the right of women to freely choose their profession. These early efforts resulted in the addition of the nineteenth amendment to the constitution that emphasized that "the rights of citizens of the United States of America to vote shall not be denied or abridged by United States or any State on account of sex" and women were granted the right to vote as one of the most significant achievements of the First Wave of Feminism. The First Wave Feminism started as an all-white movement. Protestors who demonstrated against banning women from voting were

"well-dressed, well-educated, White, middle-class women" (Offen 2) The majority of feminists of the first wave, argue Baxandall and Gordon, were white women of middle-class backgrounds, who were often oblivious to the lives of women from minority and working-class families. (418)

This Wave was followed by the Second Wave of Feminism of the 1960s. With this Second Wave, women started to be more structured building organizations and associations to support their calls for women's rights such as the right for abortion, property ownership and equal pay at work. Thus, this period, Baxandall and Gordon point out, witnessed the creation of the National

Organization for Women (NOW), (415), the WOW (Women Office Workers) in New York, WE (Women Employed) in Chicago, and WAGE (Women's Alliance to Gain Equality) in the Bay Area Union (421). The passage of Title VII of the Civil Rights Act of 1964, the formation of the National Organization for Women, passage of Title IX in the Education Amendments of 1972, the Roe V. Wade decision, and the publication of The Feminine Mystique by Betty Friedan are among the most notable events of the Second Wave of Feminism. They all marked the relative success of this wave in shaking the mainstream anti-feminist culture achieving significant successes and accomplishments.

This Second Wave differed from the First Wave in that it drew in women of color and women from developing and Third World nations, seeking sisterhood and solidarity and claiming 'women's struggle as class struggle (Rampton para 8). However, although this Wave witnessed the involvement of women of different ethnic backgrounds, 
Bearing the Burden to Neverland: Exorcising Demons of Otherness with Healing Incantations of Magical Realism in Leslie Marmon Silko's Ceremony, Gloria Naylor's Bailey's Café and Laura Esquivel's Like Water for Chocolate.

they rarely joined the mostly white women's campaigns and marches because they were offended by "the whiteness of the agenda as well as the membership" (418) of the majorly white feminists. This caused them to form their own organizations creating "somewhat different Feminisms" (418). Since they were the ones who doubly suffered, they were very enthusiastic to get their demands heard and executed. However, sometimes their demands were on a different degree priority in comparison with the demands of the white women. For instance, one of these ethnic minorities' priorities was restricting the widespread practice of coercive sterilization which was a practice they suffered from on the hands of slave owners. The Reproductive Rights National Network (known as R2N2) succeeded in restricting this practice which was not one of the issues that was considered a priority for the white women. Thus black Feminism, Asian American Feminism, and Native American Feminism were on a different coalition for their rights since they- ironically enough as these were primarily human rights campaigns-- experienced racism within these women's movement. The Second Wave was followed by a Third Wave of Feminism which started in the 1990s and continues until now emphasizing women's duty to defend their rights. This includes a preoccupation with discourses of stereotyping, post colonialism and postmodern thinking. This is also marked by deeper involvement of ethnic feminists into the picture.

The Three Waves of Feminism are closely tied to written texts. This is clear since women and writing have always combined into a form of escapade, mobilization or rebellion. Early Feminists used literary works, prose, poetry and nonfiction as well as the everyday feminine magazines as a medium for exchanging reform ideas. Women thus used different types of tapestry to express their needs and have a voice of their own-what Kyra Gemberling called feminine agendas (58). In an interesting study of the historical evolution of Feminism from the early 1770s until now, Gemberling examined the content of American women's magazines as being reflective of the evolution of the movement and a tool of communicating the ideals of the movement. Women's magazines from the early 1770s to the late 1860s, she finds out, served as early advocates of female civic participation when female subservience was a cultural norm. As these early calls for feminine civil rights started to be attained, women's magazines from the 1870s to 1970 s encouraged female independence through involvement in academia and the workplace. Finally, women's magazines from the 


\section{Dr. Rasha Mohamed Wagdy M. Elleithy}

1980s to the present day provide what can be regarded as empowering content which allows women to form their own, unique feminine identity "in an age when a better variety of lifestyle choices are available" (57). What is extremely interesting is what Gemberling notes of that the topics of these magazines was dependent not only on the editors of the magazine but also on the comments and feedback of the readers which shows the role of writing, narration and feminine written communication in the evolution, development and mobilization for the success of Feminism to attain its goals.

On the other hand, literary books, fiction and non-fiction are also reflective of the evolution of the movement. They do not serve only as documentaries of the amount of suffering and the different modes of discrimination and subjugation women suffer from in a patriarchal society. They also served as a mobilizing agent, a coded letter to fellow victims of patriarchal oppression. It was the writings of the early feminists including the liberal writings of Mary Wollstonecraft's A

Vindication of the Rights of Woman (1792), Virginia Woolf's A Room of One's Own (1929) and Simone de Beauvoir's The Second Sex (1949) that paved the way for the second wave of Feminism. Along with this liberal Feminism rose a socialist/Marxist Feminism that was initiated by, among others, Rosa Luxemburg (1870-1919) in Germany, Alexandra Kollontai (1873-1952) in Russia, and anarchist Emma Goldman (1869-1940) in the United States (korlokee 6) whose written works mobilized working women with their concern for the status of women at work focusing particularly on working-class women and their involvement in class struggle and socialist revolution" (Korlokee 6, 7). These works documented, criticized and attacked the wide range of discrimination and suffering that women, as women, were subject to. They questioned the basic premises of communal and social stereotyping of women, societal banning of political and civil rights and legal discriminatory laws and practices that facilitated such injustices. These works also mark the beginning of the history of feminist literary criticism (Plain and Sellers 6). For instance, as Susan Manly points out,

Wollstonecraft's work question the authority of Edmund Burke, John Milton and Jean-Jacques Rousseau "fellow authors of a fictitious femininity, and patriarchal enemies in league against female emancipation" where Wollstonecraft was able to expose Burke's and Rousseau's construction of an ideal, objectified woman, and the flawed misogynistic construction of Milton's Eve. (Plain and Sellers 49) There is also Virginia Woolf and her A Room of One's Own which, according to Jane Goldman, is “Woolf's richest manifesto for feminist literary Criticism" (Plain and Sellers 78). 
Bearing the Burden to Neverland: Exorcising Demons of Otherness with Healing Incantations of Magical Realism in Leslie Marmon Silko's Ceremony, Gloria Naylor's Bailey's Café and Laura Esquivel's Like Water for Chocolate.

Not only as a documentary or a mobilizing manifesto. Edith Blicksilver believes that the literature of ethnic minority women is an important new approach to understanding the causes and the consequences of social protest in the United States of America. And this in fact is true. For instance, if we take a look at a generic statistical analysis of the recession that took place in USA from 2007 to mid-2009, we will find, according to Legacy that it "took a far greater toll on the wealth of minorities than that of whites. From 2005 to 2009, inflationadjusted median wealth fell by 66 percent among Hispanic households and 53 percent among Black households, compared with just 16 percent among white households" (endnote 14, 318). This is referred to as a socio-economic aspect of being a minority citizen. Besides, according to Legacy, there is a stark discrimination against minority writers even within the scholarship of minority literature giving priority to non-black, non-gay, and non-indigenous academics in the mainstream activities and literary events. (310) Thus, meaningful research dealing with such contemporary concerns will help Americans understand why intolerance exists, and why minority groups, especially those representing women, demand a more effective role in determining their part in the future of the United States. The impact of dislocation and discrimination, the nature of inter-group and inter-generation relations, and the process of adjustment of ethnic women to the dominant male culture will also be better understood.

Blicksilver thus proposes four categories of exploration into the problems and protests of ethnic American women. She first proposes to examine their relation with the universe "God, life, love, fate, frustration and earth?" (46) Second is to explore the consequences and the effects of ethnic subjugation on them including "prejudice, discrimination and the un- fulfillment of the American dream" (47). Third, there should, according to Blicksilver, be a focus upon more specialized studies such inter-ethnic conflicts, "e.g., Black and Hispanic Americans" (48). And fourth is to study "the dilemma of intergroup relations which has resulted in the tragedies of Indian reservations, but also the unfortunate creation of relocation camps for Japanese" (50). In fact, these areas will be mostly covered within this paper since these issues are the foundation on which these works are built. There will be an exploration of their views concerning the universe and their place in it, as ethnic subject within a white majority as well as an overview of 


\section{Dr. Rasha Mohamed Wagdy M. Elleithy}

ethnic interrelations and conflicts and their impact on the ethnic woman whose suffering is thus complex and multilayered.

One of the challenges for the implementation of such a study is that Ethnic Feminism is a very controversial term and field. According to Andrea Smith, writings on Native Women and Feminism often rely on claims that "[N]ative women cannot be feminists" (309). This stems from the fact that women of color are 'objects' of abuse and discrimination. Considering them a subject of scholarship or literary theory is inapplicable. Accordingly, as Smith argues, ethnic women cannot be 'subjects' except when their work is cited "to demonstrating the racism of "white" Feminism" (309). However, this stems from even deeper issues than what Smith refers to. Feminism, as we have seen, is quite a wide term to the extent that, as Moi points out, "There is not, unfortunately, such a thing as an intrinsically feminist text: given the right historical and social context, all texts can be recuperated by the ruling powers or appropriated by the feminist opposition (132). Thus, just like the term Feminism is a wide general broad umbrella, Ethnic Feminism suffers from the same theoretical dilemma.

In fact, ethnicity does not comprise only of ethnically different suppressed subjects who suffer on the hands of the whites. For Thomas S. Gladsky, "ethnicity also means shedding old world gender roles in order to assume new world identities" (36). In these novels, the writers, who are also women, are creating narratives through which they attempt to create new world gender roles while still maintaining part of the old. This is quite problematic within the feminist context. Feminists and Feminism are, as Toril Moi describes, "political labels indicating support for the aims of the new women's movement which emerged in the late 1960s. (117) On the other hand, as an ethnic subject, while women of color tend to be what Gladsky calls, "the catalysts for change" (37), they also attempt to "emphasize particular folk customs, and holy days, their dedication to Catholicism and ultimately to the parochial school system, their cooking, their naming of children" (38). All of these activities however come as part of a patriarchal institution that Feminism is rejecting. They thus combine Feminism, femaleness and femininity in "their eagerness to fuse old and new world attitude" (38) This results in "a model of ethnicity that is at once personal and communal, basic and fundamental" (38) which is an aspect unique to ethnic Feminism. For, as Moi distinguishes between the three terms 'Feminism', 'femaleness' and femininity' stating that 'Feminism' is a political position, 'femaleness' is a matter of biology while 'femininity' refers to a set of culturally defined characteristics. (117) Thus, Ethnic Feminism presented through our writers does not reject women's 
Bearing the Burden to Neverland: Exorcising Demons of Otherness with Healing Incantations of Magical Realism in Leslie Marmon Silko's Ceremony, Gloria Naylor's Bailey's Café and Laura Esquivel's Like Water for Chocolate.

femininity or femaleness. They rather embrace it as part of the process which Melissa

Groenewold points out as 'a movimiento'.

Groenewold asserts that it is vital to remove the stigma that women of color are eternally subjects-in-process and it should be demonstrated that being created by multiple discourses is a human phenomenon rather than one unique to women of color. (93) As human beings, we are the product of our consciousness, experiences, background, race and gender. This is by no means a concrete inflexible mold. It rather contains within its structure the dynamics of flexibility, evolution, development and change. Thus, by doing this, there could be "a movimiento toward a subjected self whose agency serves as a liberating force" (93). For, since women of color had lived and experienced multiple subjectivities and were thus constantly obliged to create ways by which they will be able to communicate, adapt and react to the cruel patriarchal community surrounding them, they had their own brand of Feminism. Consequently, their experiences challenged the norm of Feminism and changed the mainstream approach to the relation between race and gender (Zinn and Dill 3). For ethnic women whether African Americans, Latinos, Native American or other ethnicities within the American structure, "gender is part of a larger pattern of unequal social patterns" (Zinn and Dill 3). Thus, these three books in particular can in fact be regarded by many feminists as degrading since they emphasize feminine stereotyping as women are presented in these works as "subjects of submissiveness, silence, patriarchal authority, or physical and psychological violence" (Al-Barazenji 146). However, they are not devoting their writing for defending women's rights. They are defending human rights. And they are doing so by reconciling the different strands that make them who they are equating their unique status as ethnic/woman status with the status of each and every individual who is the outcome of various forces. They, thus, argues Groenewold, "not only serve as excellent interpreters, but also as instructors for the greater society where difference and otherness are complicated by the close proximity in which differed peoples are operating" (93-

4).

In fact, this is what is so enchanting about these novels. They discuss otherness not as a stigma or a source of shame. Looking into the actual status of the ethnic groups to which the three writers belong, the 


\section{Dr. Rasha Mohamed Wagdy M. Elleithy}

amount of social, economic, biological and cultural injustices that they were subject to is definitely horrific. They, as, Maxine Baca Zinn and Bonnie Thornton Dill point out, have encountered severe economic and social dislocations. In colonial America, "they faced war, disease, and a deliberate program of extermination" (4). Moreover, what came to be called the 'middle passage' witnessed huge deaths among Africans who were brought from their own continent into American slavery while Mexicans were unjustly incorporated into the American community due to war dying in large numbers "working to build the mines and railroads" (4). Added to this is the general public attitude against them that was manifested in hate crimes, animosity, race riots and other types of public aggression against them (4). However, the writers do not present us with prolonged tales of whining and suffering but rather serve us with recipes for healing and remedies for resolution. Whether it is through cooking magical meals, dining in a magical café or going through a supernatural ceremony of healing and appeasement, the three novels end with a resolution and reconciliation with one's otherness and society's cruelty. They moreover imply that they are not victims. Acts of cruelty against them affect the oppressors and the whole world order as well. Being an ethnic feminist is not a pursuit for ethnic women's rights as the first glance at the term might imply. The intersection between Class (since ethnicity places the coloreds into an inferior social class), Gender and Race create a unique state for the ethnic woman. As ethnic women writers, each one of them had experiences of submission and subjugation on various levels. One level is by belonging to a minority race or ethnicity (presumed inferior race), another level is in being a woman (presumed inferior gender) and a third one is in being a woman writer (presumed inferior talent). This was conspicuously evoked by Giatryia Spivak a couple of decades ago when she wrote the groundbreaking Can the Subaltern Speak? Spivak was in this article asking a crucial question concerning the postcolonial subject who belongs to the margin and attempts to address the center. She was wondering whether the 'subaltern' is allowed to speak, is capable of speaking and whose speaking will be of any use. The status of ethnic women writers is graver. This is their own country, these are their own people, their families and friends and colleagues. There are no colonialist military forces that need to be evicted or an imperialist country that needs to be fought. The fight is from within against one's own. As a woman who has to start a reform within a family, she does not get equipped with arms and guns against them. She does not fight them. She starts singing a lullaby to the kids, serve a delicious hot meal to the husband, and tell a magical story to the family that would take away the 
Bearing the Burden to Neverland: Exorcising Demons of Otherness with Healing Incantations of Magical Realism in Leslie Marmon Silko's Ceremony, Gloria Naylor's Bailey's Café and Laura Esquivel's Like Water for Chocolate.

pain transforming it into a power of love, unity and forgiveness. And this is exactly what our women/writers do using the technique of Magical Realism. Magical Realism, Magic Realism or 'marvelous realism' are terms that are, as Maggie Ann Bowers states in her book Magic(al) Realism (2004) "notoriously difficult to define" (1). The three terms however refer to the trend of merging magical elements with realist writing. According to Bowers, the consensus among most contemporary critics, assert that it was the German art critic Franz Roh (1890-1965) who first introduced the term "to refer to a new form of postexpressionist painting during the Weimar Republic" (8). These paintings, as Bowers asserts, were mostly characterized by great attention to detail, a photographic like outlook and the representation of the supernatural qualities of nature and the trans-real of reality (8) then, as On the 1950s, Magical Realism started to be used in relation to fiction, and has since been adopted as the main term used to refer to all narrative fiction that includes magical happenings in a realist matter-offact narrative (2).

In these narratives, magic is not used as a supernatural or an extraordinary feature, but part of the everyday life. As Bowers points out, Magical Realism

"relies most of all upon the matter-of-fact, realist tone of its narrative when presenting magical happenings. For this reason, it is often considered to be related to, or even a version of literary realism" (3). As Bowers asserts, "[T]he variety of magical occurrences in magic(al) realist writing includes ghosts, disappearances, miracles, extraordinary talents and strange atmospheres but does not include the magic as it is found in a magic show. Conjuring 'magic' is brought about by tricks that give the illusion that something extraordinary has happened, whereas in magic(al) realism it is assumed that something extraordinary really has happened" (19). However, what could be included as a Magical Realist work does not necessarily comprise of all these elements. As Wendy Faris in "The Question of the Other" asserts, when describing her criteria of inclusion for works of Magical Realism, the basic element for inclusion of the work in the category of Magical

Realism is "the existence of an "irreducible element" that is unexplainable according to the laws of the universe" (102). What distinguishes Magical Realism from Realism, Bowers argues, is that it fuses the two opposing aspects of the oxymoron (the magical and the realist) together to form one new genre that relies on the reader's 


\section{Dr. Rasha Mohamed Wagdy M. Elleithy}

acceptance of this fusion as normal (3). Bowers states that Magical Realism has become a popular narrative mode that is favored by writers who want to write against totalitarian regimes. This technique is used, as Bowers asserts as a means to "attack the definitions and assumptions which support such systems... by attacking the stability of the definitions upon which these systems rely" (4).

Maria Ruth Noriega Sanchez explores magical realist works. She points out that they display basic distinguishable features from other works of other genres.

First, Sanchez argues, they show a "Dialogic encounter of two cultures, reflected in the language of narration" (14). According to her, in these works, there is a juxtaposing of a rational realistic view against a magical one. The rational realistic view is based on a Western cosmology while the magical view comes from ancient non-Western systems of belief and folklore (15). There is also in these texts, she argues, a simultaneous presence of two codes of reality, the natural and the supernatural and these two codes constantly slip into each other. Sanchez points out that it is significant that the insertion of the supernatural is not problematized at all but presented in a matter-of-fact way as part of a coherent Weltanschauung and these boundaries are "explored and transgressed" (15). These texts, as Sanchez argues, put into question the received ideas concerning time, space and identity. Sanchez proposes a dichotomy in which magic is reflected in NonWestern concepts while realism is reflected in Western ones and the tension between magic and realism is mirrored in the conflict between Western and non-Western concepts of time and space. Consequently, notions of identity, especially in relation to race and gender, are explored and challenged which leads in turn to the production of texts that take an "anti-bureaucratic position" (15) using magic to subvert the established social order. As Sanchez asserts, Magic Realism "offers a multiplicity of codes that forces a re-visioning of history and motivates political action, urging the reader to create alternative models for reality. Due to these features, it proves to be a literary mode particularly useful to writers who belong to cultures which have been displaced from their land of origins and confined to the borders" (20). She asserts "Magic realism carries an element of resistance toward the imperial center that makes it most operative in cultures situated at the fringes of mainstream literary traditions." (21) These features explored by Sanchez are the basic distinctive features of Magical Realist works.

While they employ the Latin American technique of Magical Realism as means for opposing the status quo, the way they employ it is totally distinctive of them as ethnic women writers where the label 
Bearing the Burden to Neverland: Exorcising Demons of Otherness with Healing Incantations of Magical Realism in Leslie Marmon Silko's Ceremony, Gloria Naylor's Bailey's Café and Laura Esquivel's Like Water for Chocolate.

Magical Feminism is most suited to them. As Kimberly Ann Wells states, "what the writers who are working within Magical Feminism are doing is teaching feminism" (23-4). She asserts that one of the best features of Magical Feminists is that they accompany the reader to journey in which gender roles are not only blurred, they are totally reversed and women are portrayed as endowed with the power necessary to change the world. In such a tale, women restructure the word through healing and mending what 'the others' had messed up. Added to what Wells asserts is that from the other perspective, such a powerful storytelling is necessary for women. In reality, women do not use magic. They can't but they could definitely benefit from the belief that they can, that they are capable human beings, that they are subjects and not merely objects. This is achievable through a series of actions, evocations and spells to create a balanced world in which maternal values of love, sacrifice, healing, and fairness rule.

Leslie Marmon Silko's Ceremony employs the technique of Ethnic Magical Feminist writing not only as a means of dealing with the burden of Otherness with all its pain and shame, but also to create a beautiful and fair world out of it. Being born in Albuquerque, Silko is of mixed ancestry: Laguna Pueblo, Mexican and white. In her book, she traces the story of Tayo, an ex-soldier in the American troops during the Second World War who suffers from post-war trauma. The core of his psychological upheaval is the shame and pain of his hybrid nature as a Mexican Laguna Native American who had fought for the country that rejects him and his identity. Throughout the novel, we accompany him in what Claudia Eppert describes as his journey of "remembrancelearning" (727). In this journey, he goes back to his hometown reservation and starts into a healing process in which he must "unlearn colonizing discourses and exercise native ancestral memories that he had abandoned or repressed" (727). This process, this ceremony in which the muses of Mexican Laguna ancestry are evoked, results not only of the healing of Tayo but also in restoring balance to the universe that had been unbalanced due to the evils of witchery that resulted in the unleashing of the powers of evils exemplified in colonial and ethnic discrimination. The opening epilogue of the book is quite telling of what the coming pages will carry: 
Dr. Rasha Mohamed Wagdy M. Elleithy

Ts'its'tsi'nako, Thought-woman is sitting in her room and whatever

she thinks about appears

She thought of her sisters,

Nau'tsi'ty'I and I'tcts'ity'I, and together they created the Universe

She is sitting in her room thinking of a story now

I'm telling you the story she is thinking. (1)

Silko builds for the reader the world of Native American magical world from the opening lines of the book and sets the narrative rules for the reader. The reader is directed to knowing that he is getting into a magical world that is magically crystalized into becoming a reality by the utter act of thinking about it by the "Thought-woman". We are told that "The Thought-woman" has a magical double power: she has a strong imagination for creativity, and she has the power to make what she thinks real. The Thought- woman had created the universe through thinking about it and just as the universe is the creation of the Thoughtwoman, so is the upcoming world of the novel. With this epilogue, the reader becomes not only a spectator of the world of the novel. He moreover becomes a witness to a magical moment of creation, a witness to a 'the presence' of that which was before only 'thought of'. So, as the readers starts this book, he is actually sharing in Silko's magical incantation of creation armed with the belief that what is being told, is real, just as the universe which he was created in. Through this cunning literary trick, Silko is not writing a novel. She is creating a universe of equality, of respect for ethnicity, for the victory of the sacred ethnic deities of the Mexican Laguna ancestry who regain power of the universe of the written text, a power that they have lost in the universe of the writer. She is thus populating her imaginary world with readers who accept to connive with her in her literary conquest.

In the next page of the novel, more is revealed about the magical incantation used by Silko to create the world of the novel. Another homage to the 'Thought' maker is made by the story-teller. The role of the storyteller, a typical role of women in the feminist context, is given to a man, who, though a male, carries out typical feminine activities. The first activity is that of storytelling: "I will tell you something about stories,/ [he said]" (2). He tells stories not as a male, but as the storyteller, while the Thought woman creates, not as a woman, but as a creator. It is significant this is the role-integration that Silko builds. Besides storytelling, he takes on another typical duty of women: bearing 
Bearing the Burden to Neverland: Exorcising Demons of Otherness with Healing Incantations of Magical Realism in Leslie Marmon Silko's Ceremony, Gloria Naylor's Bailey's Café and Laura Esquivel's Like Water for Chocolate.

children. He assumes a maternal role in this magical world in which gender roles are not reversed per se. They disappear. He does not only tell the stories; he also nurtures the stories inside his womb until they are told. In that magical world, a woman's biological nature of bearing children is given to a man who carries in his belly little stories: "He rubbed his belly./I keep them here/ [he said]/ here put your hand on it/ See, it is moving./ There is life here/ for the people" (2). The role of nurturing the embryo till it is full and ready to be born/ told is also highlighted: "And in the belly of this story/ the rituals and the ceremony/ are still growing" (2). And what is being kept and born is not an insignificant rudiment. These stories, Silko emphasizes are not entertainment stories: "They aren't just entertainment... They are all we have, you see,/ all we have to fight off/ illness and death" (2). In this world, the world of the novel and the world of the Native American, storytelling is a survival kit and the oppressors and the powers of evil realize the power of storytelling. Their best bet is always to silence those striving for their rights and telling one's story is the most powerful thing that can be done in the face of them. However, "[T]heir evil is mighty/ but it can't stand up to our stories./ So they try to destroy the stories" (2).

On the other side, whereas in Ceremony, Silko takes the reader into a journey of what Eppert calls "remembrance-learning", Gloria Naylor in her novel Bailey's Café takes the reader through a journey of "forgetting- learning". For, whereas Tayo, according to Eppert, is made to go through a process where he is required to remember his ancestral roots and to adapt to the different strands that make up his identity, Naylor constructs a cafe in which its clients, and the residents of the nearby hostel are made to go through a process of elimination and forgetting of all the difficulties and hardships they went through in order to survive. Naylor teaches her residents, whether her characters, the Bailey's Café's clients or her sympathetic readers, to learn how to forget, how to eliminate, and how to survive all the stereotypical patterns connected with the dark skin color of the African American subject and specifically African American women. In an interview with

The Seattle Times, Naylor explains that her novel's underlying theme is "how people define femaleness and female sexuality, how women have been cast in sexual roles since Eve". This is very clear as we scan the different characters of the novel beginning with Eve--the name is significant of course as it recalls the alpha woman in humanity. 


\section{Dr. Rasha Mohamed Wagdy M. Elleithy}

Eve owns a hostel/ brothel that embraces different women of different backgrounds who are basically victims of sexual and psychological abuse and whose identities and bodies as women was the reason they were severely manipulated, ravaged and exploited sexually, physically and socially.

Whereas Ceremony starts with a poetic epilogue, Bailey's Café starts with a melodious overture. In the first page of the novel, Naylor sets the mood for the novel "Maestro, if you please..." (2), and as the imaginary musical intro plays at the back, the story begins. Mr. Bailey, the cafe's owner and the novel's narrator prepares the reader to a visit that would teach them much more than any education since "school isn't where real learning happens" (3). He shows us that gender discrimination activities and ethnic injustices are real life experiences and not just in books. That is why he asserts that "this cafe is earning [me] a PhD" (3).

As a cafe, it is supposed to be a place that feeds the body with food and the soul with music. However, this café in particular is different for although it attracts guests "from all over the United States and some parts of the world" (3), it makes "lousy coffee" and bad food and has no attracting assets. This contradictory information implies a secret that the reader should not expect to get "in a few notes" (4). This secret is revealed when the reader gets to know him and his customers. And as Mr. Bailey starts to speak about himself and about his customers, he directs the reader "to stick around and listen to the music" (4) as "there is a whole set to be played" (4). By the end of the chapter, we understand the nature of the secret. This cafe is a magical cafe that is "really really mobile" (28). That is why he made sure to serve bad food so that people won't think that this is a real café and start to ask questions "why wasn't this place here last month when I came by? I could see if you'd just closed down-but the whole damn building was gone" (28). He explains the reason for the existence of the café:

Even though the planet is round, there are just too many spots where you can find yourself hanging on to the edge just like I was; and unless there's some space, some space to take a breather for a while, the edge of the world-frightening as it is-could be the end of the world, which would be quite a pity. (28)

Bailey who starts the novel narrating how he met his wife, delivers a strong message early off on how women should be seen and treated. He was physically attracted to her who "looked like an American goddess" (13), looking for a chance to be with her, expressing his disappointment that she was not interested in going to movies, not 
Bearing the Burden to Neverland: Exorcising Demons of Otherness with Healing Incantations of Magical Realism in Leslie Marmon Silko's Ceremony, Gloria Naylor's Bailey's Café and Laura Esquivel's Like Water for Chocolate.

because he likes movies but because he was "looking for ways to be with her alone in the dark" (15), she managed to teach him a lesson, "a lesson, and a whole different way of looking at her-and women" (19). While he was only attracted to her outside appearance, misunderstood her reactions and gestures, was always convinced that she was not having a good time with him, was unhappy, to which she would respond "I don't know what you're talking about. I enjoy myself every time we're here" (17), he learned to look behind her outside appearance. Only then, "looking deep into her eyes, I saw that she was laughing. Down at the bottom of those dark orbs, she was bent over double and howling. She laughed and laughed and laughed" (19).

Following this didactic episode concerning the treatment of women, we are introduced to a Tayo episode so to speak. Describing his upbringing in Brooklyn "the capital of the world" (4) as a poor colored boy, his inferiority was intensified as a colored American and a poor one whose parents cooked for rich colored families. As he puts it, "I had it figured out pretty good for a five-year-old: there were rich white people, poor white people, rich colored people---and us" (4). When he grew up, in spite of this feelings, he was obliged to serve in Japan for fear of getting imprisoned. Similarities between the ethnic and racial segregation experience is astounding: fighting for a land that did not consider him one of its one, failure to kill or fight as expected from him, and the impact of the war on him

(21-7). However, unlike Tayo's psychological suffering, Bailey accepts everything: "[T]hey had been living with segregation, and so how did they figure the navy expected them to die without it" (22). He understands that he will be

"judged as a coward. But I couldn't march into Tokyo. I feared for my immortal soul" (23).

And whereas Silko takes the reader into a journey of healing through what Eppert calls "remembrance-learning", Naylor takes the reader through a healing journey of 'forgetting- learning', while Esquivel takes the reader through a healing journey of 'remembrancel forgetting- learning'. In Like Water for Chocolate, victims of social and ethnic persecution learn to recover, to reach the upside of anger, pain and insanity resulting from sexual and social oppression specifically exemplified in the narrative of Tita and her sisters. The storytelling is assigned to a female which reflects Esquivel's interest and acceptance of stereotypical gender roles- an interest that will continue throughout 


\section{Dr. Rasha Mohamed Wagdy M. Elleithy}

the novel. As we read the first pages and through the whole novel, Esquivel seeks to evoke beauty, power and healing through an intensification and not an alteration of the negatively stereotyped roles of women, of bearing children, cooking, telling stories and other socially accepted and induced 'feminine roles'. She also assigns most the evils coming out of these roles not in the nature of the role but rather in the cultural and social

(mis)understanding of it. In fact, everything about the novel is unique. From the title "Like Water for Chocolate" to the subtitle "A Novel in Monthly Installments, with Recipes, Romances, and Home Remedies" to the structure of the novel being divided to 12 chapters, a chapter/ recipe for each month and each recipe includes a magical or fantastical ingredient. The title is unique in many ways. For one thing, it compares something's effect to what water does for chocolate and besides this omission, the remaining part is quite vague, for, after all, what has water to do with chocolate? The subtitle also includes a unique mixture where the monthly installments include food, passion and healing - "Recipes, Romances and Home Remedies". The epilogue to the novel that reads "To the table or to the bed/You must come when you are bid" (3) is a manifesto for women's stereotypical role in life: to serve or to be there for sex. A role that is played whenever she is 'bid' or requested by the man.

In the very first page of the novel is the recipe for January, the first month of the year and it is a traditional Mexican dish with its distinctive ingredients:
1 can of sardines
$1 / 2$ chorizo sausage
1 onion
Oregano
1 can of chiles serranos
10 hard rolls

And then starts the cooking guide as Esquivel admits us to the kitchen, to that sizzling pot of pain, sexism and oppression that women fall victim to. We are admitted to the kitchen where she cooks for us her story and where the majority of her protagonist's actions take place throughout the novel. The kitchen in this novel is not really just a setting. It is rather a character that interferes in the action driving it in different directions. With the kitchen, we are also introduced to Tita through the words of her granddaughter who is the narrator to the whole novel. Along with Tita, the kitchen and also Nacha the half-deaf cook, we are introduced to the magical elements in feminine 
Bearing the Burden to Neverland: Exorcising Demons of Otherness with Healing Incantations of Magical Realism in Leslie Marmon Silko's Ceremony, Gloria Naylor's Bailey's Café and Laura Esquivel's Like Water for Chocolate.

stereotypical activities wrapped in typical feminine sentiments and emotions. This includes chopping onions to which Tita was sensitive to when she was in her mother's womb to the extent that Natcha, the cook, could hear her sobbing. Her sobbing as an embryo became so violent to the extent that she brought about an early labor to her mother $(5,6)$. Her birth was on the kitchen's table in the middle of her tears that "spilled over the kitchen table and flooded across the kitchen floor" (6). Those tears after being dried left a residue of salt that was "enough to fill a ten-pound sack" (6).

Through the opening lines of the three novels, we are not only introduced to the magical world of these novels. We are introduced to the basic characteristics of the native ethnic culture of each writer with strong and direct references to iconic symbols of that culture. This is especially significant since a major of the characteristics of Ethnic Feminist Magical Realism or Ethnic Magical Feminism is an emphasis on ethnic culture and traditions that are usually mocked, attacked and used as a criterion for discrimination by others. Women, the carriers of civilizations and the caretakers of traditions and cultural heritage carry out their sacred task of protecting and defending the heritage of the ancestors by representation, exploration, evocation and veneration. As feminist writers, they explore the evils of gender discrimination and misogynist discourse and as ethnic American writers, they highlight the evils of racial discrimination and colonialist discourse. As ethnic feminist writers, they double task as they explore the doubly subjugated Native American/ African American/Mexican American women through an atmosphere of magic. They thus combine two major characteristics of Ethnic Magical Feminism--magic and heritage-which is clear from the opening pages of each novel. Added to this is an emphasis on the power of storytelling as a tool for (re)creation, rebellion and healing.

In Silko's Ceremony, we are admitted into the magical world of supernatural beings and imaginative worlds through the introduction of the Thought-woman and the story of the creation of the universe. This is done through asserting an important characteristic of Native American culture which is folktales and oral tradition through the story being told by the narrator who carries the stories inside his belly. This mode of reporting stories will continue throughout the book since the act of 'saying' is very significant for this culture. Another significant trait of Native American culture is that it is a matriarchal culture which means that great importance is given to women as the foundation and initiator 


\section{Dr. Rasha Mohamed Wagdy M. Elleithy}

of the family, community and the whole universe. The thought-woman is the creator of the universe through her act of imagining it which reflects the position of the female in this culture in which the most powerful deities are portrayed in female figures and the woman is the core of fertility, growth and extension for the family. Intensifying this role is achieved through mirroring women's powerful act of 'bearing' children in the act of bearing stories by the storyteller. For the urban American world who does not give the same position of importance or sacredness to women, Silko addresses them in clearer images. The less sociallyrespected role of women as children's bearers are assigned to a man whereas the extension of the role of women as bearers of children which is being the core of society and in turn the whole universe is presented through the Thought-woman who is a metaphysical god who is responsible for creating the universe and anything that survives on it. Another characteristic of the Native American culture is its universal outlook which is also apparent in the novel where the absence of time is clear. Stories, rituals and incidents 'are still growing', no past or future, just present.

On the other hand, Naylor introduces us also in the opening lines of her novel to the dilemma of the African American subject whether man or woman. As an African American woman who was brought up in New York, she echoes what she has witnessed in her life in the novel that is set in Brooklyn, New York. Within a few pages, we are able to grasp the basic characteristics and challenges of that culture especially for women mixed with the mystic touch of Magical Realism. In these few pages, we are introduced to the basic features of Ethnic Magical Feminism namely emphasis on cultural ethnic specificity and the magical element of the novel. We witness the basic features of the black American culture.

Assigning the setting of the novel to Brooklyn, the capital of New York for African Americans and other ethnicities, Naylor roots her reader in the African American milieu where we are introduced to the hierarchal construction of the American community through the eyes of an African American boy who occupies the bottom of the American sociocultural ladder. Like Ceremony, the opening lines introduce us to a gender role reversal as a means for attaining gender roles abolition. Thus, and while the novel-Bailey's Café-- is an act of storytelling done by a woman-Gloria Naylor-- in a discriminating society, her first outcry against stereotyping, against her helplessness as a woman who has got nothing but a voice, is to reject that stereotyping. Like Silko, she assigns the act of storytelling in her dreamy world of the novel, her handmade universe that spans the range of the pages of the novel, to a 
Bearing the Burden to Neverland: Exorcising Demons of Otherness with Healing Incantations of Magical Realism in Leslie Marmon Silko's Ceremony, Gloria Naylor's Bailey's Café and Laura Esquivel's Like Water for Chocolate.

man who is kept in the background as a marginal character to her leading characters. She thus keeps his name anonymous where 'Mr. Bailey' is only a nickname. One the other hand, all the women characters, including Bailey's wife, are given names. Moreover, we are introduced to the magical fairytale element in the novel which is the mysterious café which attracts everybody in the world and whose secret unfolds as we go through with our visit to the café while the music plays in the background.

In Like Water for Chocolate, the cultural traits of the Mexican tradition are clear from the very beginning. It is important to note the historical facts concerning the Mexican American relations as to understand the location of the Mexican tradition within the American culture. A large section of what is now known as the United States of America--namely Texas, New Mexico, Arizona, Colorado and California--was originally Mexican land. This land along with 100,000 Mexican citizens living on it were annexed after the U.S. -Mexican war of 1846-48 and became American with the signing of the Treaty of Guadalupe- Hidalgo 1848 ((Sanchez 179). Those of Mexican origin on the two sides of the border have a distinct culture, heritage and suffering due to their colonial experience. Like Water for Chocolate is set in Mexican Coahuila, on the U.S. -Mexican border, at the turn of the twentieth century and is thus rich in Mexican sociocultural allusions and traditions. The recipes in the beginning of each chapter are real recipes from all over Mexico that are crammed with Mexican herbs and flavors "that reinforce the links to a pre-Hispanic past and the notion of a distinctive ethnic identity" (Sanchez 217). These recipes are not just an emphasis on the Mexican heritage within an American/Mexican tension but also a reference to the role of this novel within the Mexican patriarchy/ femininity tension. The narrative is introduced within a milieu of tears and crying that is so hard that it floods the kitchen, and its residue is deep and lasting that it can fill 'a ten-pound sack'. Tears and moaning that reflect on the fate of Tita who is endlessly subjugated and oppressed with social and cultural ties. The title of the novel can only make sense within a Mexican context as it is a Mexican idiom that is used to refer to someone who is so irritated and angry and is thus 'like water for chocolate'. The idiom in itself carries Mexican ancestral associations as native Mexicans who did not have cows had to boil water to have their chocolate. That moment of the water reaching the temperature of boiling is the right moment to add chocolate to the water 


\section{Dr. Rasha Mohamed Wagdy M. Elleithy}

(217). Even the format of the novel is built over the format of old extremely popular Mexican magazines that were written for women by women including recipes, home remedies, and stories (called there calendarios para sefioritas) (217-8).

The three novelists provide us with narratives that present us with three ethnic American recipes for healing from the evils of discrimination and marginalization. In Ceremony, we accompany Tayo in his healing process and in his journey we witness Silko's magical incantation. As Sanchez rightly points out, Silko uses Magical Realism in her writing "in order to hybridise the conflicting ontologies of Native American culture and Western culture, with the aim of offering new ways of seeing, new and larger realities" (140). Throughout the novel, there is a juxtaposing between Native American and Western values and culture. From a glance, one might feel that they are juxtaposed in order to favor one over the other. Silko as a Native American who is writing a novel about a culture that has been suppressed, persecuted and oppressed could be more likely to defend the values and ideals of that culture when contrasted to a colonial culture. However, in this novel, she attempts to reconcile the two conflicting worlds through a magical incantation that does not only reconcile the world of the Laguna population with the Westerners' world, but also the physical with the metaphysical, the human with the universal, reality with magic.

As the reader starts reading the novel, Silko's attempt to merge the different worlds of Tayo in her narrative causes a temporary confusion as she jumps from one mode to another without hints. Tayo's nightmares that require a ceremony to be discharged is a mirror of Silko's narrative as a reflection of the world of the Laguna citizen who lives on the borders of different cultures, values and conflicts all at once:

Sometimes the Japanese voices came first... and then he could hear the shift in his dreaming... and the voices would become Laguna voices... and he heard the women's voices then ... he thought the Laguna voices where his mother's but... the voice suddenly broke into a language he could not understand; and it was then that all the voices were drowned by the music-loud, loud music from a big juke box, its flashing red and blue lights pulling the darkness closer. (6)

This is neither a chronological nor an episodic trauma. It is an all-at-once conflicts, memories, challenges and suffering. The Japanese voices from his military service time during World War II is tangled with his homeland's voices breaking into a third ambiguous language. All of these voices were covered by the loud noise of nationalist calls by 
Bearing the Burden to Neverland: Exorcising Demons of Otherness with Healing Incantations of Magical Realism in Leslie Marmon Silko's Ceremony, Gloria Naylor's Bailey's Café and Laura Esquivel's Like Water for Chocolate.

the American authorities with the flashing lights of the distinctive colors of the American flag-red and blue--that had sent him into a war against America's enemies although he was never really considered or dealt with as a genuine American. In fact, World War II only caused his hybrid breeding trauma to surface since his ordeal has always been there. His lack of sleep as a sign of his inner suffering started lately "for as long as all things had become tied together like colts in single file.... He could get no rest as long as the memories were tangled with the present, tangled up like colored threads" (6).

Ku'oosh is the carrier of Silko's healing incantation which consists basically of three ingredients-what might be called the three ingredients of knowledge--for the magical incantation to work for Tayo, and by extension for us as readers. Ku'oosh's first ingredient has to do with the act of storytelling itself. This ingredient, as Ku'oosh carefully explains to Tayo, is the knowledge of the right choice of the words "because no word exists alone, and the reason for choosing each word had to be explained with a story about why it must be said this certain way" (35). This is a "responsibility that went with being human" (35). Thus, Silko, through Ku'oosh, emphasizes that storytelling and the right choice of words are remarkable human faculties. In fact, they are faculties that ONLY humans could perform, and thus this separates humans from non-humans. It thus becomes clear that Silko's novel is not simply a narrative of a series of incidents. It is a carefully chosen series of words in which one word is chosen specifically for a certain reason.

With this one sentence, Silko summarizes one of the most powerful features of literature, or arts in general. The power of art which is, as Wordsworth simply describes, "an overflow of powerful feelings recollected in tranquility", is the power of choice. Artists excel other humans in their ability to choose from among the many words or signifiers that would refer to the same meaning or signified as Roland Barthes calls them. An artist, a healer, is someone who fills a white paper with a number of carefully chosen words that would end up healing the reader; that would take the reader into an Aristotelian catharsis. Religious scriptures and spiritual psalms are nothing but a number of words that are carefully chosen and ritually recited. If one had to go into an analysis of them, it would only lead to further storytelling, to further narratives that would explain why this word, this specific signifier was chosen instead of the other similar signifiers-a large branch in religious studies (Tafsir or interpretation in Islam for 


\section{Dr. Rasha Mohamed Wagdy M. Elleithy}

instance)-is given to this area. Silko's narrative, this Native American writer's narrative would become a healer incantation when a series of choices are made right: the choice of the topic, the choice of the characters, the choice of the setting and most importantly the choice of the words. On the other hand, humans universal healing is a matter of choosing. Humans should choose to be kind. They should choose not to hurt or despise or oppress others for their ancestral roots or geographical orientation. A location on the map that is reflected on skin color or hereditary features should not make some people more eligible for kindness and respect than others. And by making this conscious choice, universal healing and peace is attainable.

The second and third ingredients of knowledge are connected. The second ingredient of knowledge comprises in the realization that "this world is fragile", and that this fragility is "filled with the intricacies of a continuing process" (35). These pillars are extremely significant since most discriminatory activities come from individuals who seem to assume that the world is a static cold concrete entity which is divided into blacks and whites, masters and slaves, superiors and subordinates. Whereas the universe is filled with all of these categories, indeed they are not divided ethnically, racially or religiously. The world is not as concrete as it might seem to some who assume the status of the superior master. In fact, the very act of discriminating against a certain person or certain category, and due to the fragility and the dynamicity of the universe, this act (or acts) lead to a series of changes that further negatively affects both oppressor and oppressed.

The third ingredient is connected to that notion of the fragility of the world which is that one person's imbalance leads to the imbalance of the whole universe. That is why when Ku'oosh explains the necessity for Tayo to get well, he emphasizes that his sickness and healing is not only important for himself but to that whole universe as: "It is important to all of us. Not only for your sake, but for this fragile world" (36). Thus, one man's imbalance, suffering and disparity affects the balance of the universe. In a world that is basically built over different ethnicities, races, colors and even species, human racism and racial discrimination are causes for chaos and imbalance in the universe by rejecting diversity and oppressing difference or otherness.

In fact, this seemingly idealistic fairytale-like notions of the fragility of the world and the effect of one person's oppression on the balance of the universe can be supported by science. This could happen through what is called 'the butterfly effect' which is in connection with a wider theory-Chaos Theory. Preceded by a number of studies and discoveries surrounding Chaos Theory and its determinists and the 
Bearing the Burden to Neverland: Exorcising Demons of Otherness with Healing Incantations of Magical Realism in Leslie Marmon Silko's Ceremony, Gloria Naylor's Bailey's Café and Laura Esquivel's Like Water for Chocolate.

different elements in that affect, Edward Lorenz gave a speech titled Does the Flap of a Butterfly's Wings in Brazil Set Off a Tornado in Texas. This speech was given at the 139th meeting of the American Association for the Advancement of Science in which he presented his theory that was published in a seminal paper titled "Deterministic NonPeriodic Flow". In simple terms, Lorenz was conducting a study related to atmospheric predictions. During his work, he had to repeat part of the computational numerical calculations. In the process, he made an approximation of one of the numbers to a 0.0001 value. When he did that while repeating the exact same processes which he had carried out earlier, the result was a totally different atmospheric prediction pattern. At first, he thought the computer was malfunctioning and planned to call the maintenance team. But in order to make it easier for them to fix the problem, he started to trace his steps from the beginning to find at which point did the computer started malfunctioning. This led him to discover that this very minute change in the numerical values, which was a wellknown mathematical approximation method, led to extensively different results when applied to real atmospheric conditions. ("Chaos at Fifty") He realized that the whole world is intricately inter-connected in a way that one very trivial and minute change in one value could lead to a catastrophic outcome. And thus, a small flap from a butterfly's wing in Brazil would cause a series of effects that could lead to as much as a tornado at another place of the world. And thus, Ku'oosh's fear from the consequences of the failure in Tayo's healing process: "I'm afraid of what will happen to all of us if you and the others don't get well" (38) start to make sense on both levels: superficially and scientifically.

Tayo's problem was his realization that because of his ethnicity, race and skin color, others decided to treat him as a less of a human being than they are. This realization was intensified by his obligation to serve in an army for a country that selectively consider him one of them. By becoming an American soldier at the time of World War II, Tayo underwent a transformative experience in which he enjoyed the respect and pride of being 'American'. This meant that he was treated beyond his skin color and ethnic origin. He was dealt with by gestures of equality and impartiality and thus his sense of belonging was stressed through a series of simple but significant actions from the other Americans. These gestures that signified his Americanism included simple activities of the everyday life of a 'normal' white American. Thus, Tayo felt that "[B]elonging was drinking and laughing with the 


\section{Dr. Rasha Mohamed Wagdy M. Elleithy}

platoon, dancing with blond women, buying drinks for buddies born in Cleveland, Ohio" (43). During the war, the white women who "never looked at [him] until [he] put the uniform" started "crowding around" (40). Blonde girls would come up to him, asking him to dance. They "never asked [me] if [I] was Indian" (41). When he walks with his cousin in the street, an old woman "rolled down the window and said, 'God bless you, God bless you'” (41). These simple gestures accumulated to enhance his feeling of belonging to that country, to those people who are so different in skin color from him, who are actually closer to those Japanese he was ordered to fight since both had white skin but who share the same land, flag and nationality.

However, this attitude of others towards him was due to the 'uniform' of his military service in the US army, 'the white mask', to borrow Frantz Fanon's terminology of his book Black Skin, White Masks. Although Fanon in his book speaks basically about the split of consciousness that colonial subjects suffer from, in Tayo's case the eruption of his ordeal accompanied his realization of his need for a mask to cover his skin as the only means for receiving the respect entitled him as a human being. Thus, that woman whose blessings seemed to be directed to him and his cousin, he realizes, was in fact praying for the country and not them:

"it was the uniform not them, she blessed" (41). And so, when the war was over and the uniform was gone: "that man at the store waits on you last, makes you wait until all the white people bought what they wanted. And the white lady at the bus depot, she is real careful now not to touch your hand when she counts out your change" (42).

This comes in direct contrast to the beliefs he was raised on. The beliefs of his tribe that humans are part of the universe in which there is respect and love among all the different creatures. In the novel, Silko juxtaposes three worlds: the mythical imaginative world of the pueblo population of an ideal harmonious world where acts of hatred or discrimination are unacceptable and even punishable, the world of an ideal Equal-Americans where there is no ethnic or racial distinctions under the pan American world of an ideal USA which Tayo and other ethnicities witnessed during the war when they were considered heroes fighting for their country with complete disregard to his skin color and the real world of ethnic, and racial discrimination. The mythical world of the pueblo population is sustained through a number of digressional poetic passages alluding to the myths and basic beliefs of the tribe. The worlds of ethnicity and racial discrimination are constantly contrasted through the eyes and emotions of Tyo before, during and after the war. 
Bearing the Burden to Neverland: Exorcising Demons of Otherness with Healing Incantations of Magical Realism in Leslie Marmon Silko's Ceremony, Gloria Naylor's Bailey's Café and Laura Esquivel's Like Water for Chocolate.

Silko parallels Tayo's relation with the universe with the historical myths of the

Pueblo. In the core of Tayo's-and by extension Silko's-culture is the belief that all creatures are born with a mission, for a reason, no creature is less important or less significant than another including animals and insects. This conviction stresses that each creature's mission is part of a greater plan of the universe and any glimpse of disrespect or ungratefulness to that mission is punishable in a way that would affect the whole universe and its balance. This is clear even in their traditional rituals that is carried out after hunting an animal: "[T]hey sprinkled the cornmeal on the nose and fed the deer's spirit. They had to show their love and respect, their appreciation; otherwise, the deer would be offended, and they would not come to die for them the following year" (51). The death of the deer to become their meal was not an act of cruelty of their part. It was rather an act of love from the deer: "They said the deer gave itself to them because it loved them, and he could feel the love as the fading heat of the deer's body warmed his hands" (52). The deer is the animal which Tayo identifies himself with. With his suffering from nightmares after his return from the war, he could only be able to sleep when he dreams of "something that existed by itself, standing alone like a deer. And if he could hold that image of the deer in his mind long enough, his stomach might shiver less and let him sleep for a while" (7). An act of kindness even to a dead deer is required to maintain the balance of the universe. The same goes for Tayo who stands as a lonely deer on borders of many grounds, yet belonging to none.

It thus becomes clear the horrendous repercussions of racial discrimination within the Pueblo Laguna context and their belief in the unity of the universe. Silko stresses this through presenting the mythical story of Corn Woman who, according to the main Pueblo myth, was angered by the sloth and indolence of her sister Iktoa'ak'a'ya-Reed Woman who was always taking a bath by the river, not carrying out her tasks properly. Consequently, Corn Woman scolded her sister and took away the rain, a symbol of heaven's blessings on earth, the source of life and fertility on land for the plants, animals and humans in the Pueblo's mythical world and thus "Everything dried up/ all the plants/ the corn/ the beans/ they all dried up" (13). In Tayo's world, the rain did disappear. However, it only happened after increasing the suffering for him and his colleagues during the war. The "unending rain" (11) kept 


\section{Dr. Rasha Mohamed Wagdy M. Elleithy}

disturbing them filling the land with swamps which was a source for an epiphany to him. His world, his worth and value, what he knew and understood were all different in his world from the 'white' world. What he believed is good and beneficial-like the rain-is not in all cases good and beneficial: "It was there that Tayo began to understand what Josiah had said.

Nothing was all good or all bad either; it all depended" (11). This distortion and disorientation of values and meanings was a significant element in causing Tayo's ordeal.

But Tayo's case was not only a reflection of ethnic prejudices. It was also a state of gendered biases and sexist conceptions. The disgrace Tayo held within the Laguna population was not that he was half-bred per se. It was specifically because he was the son of an Indian woman and a white man. Unlike the less disgraceful opposite combination of an Indian man and a white woman, the idea of a colored man having a relation with an Indian woman was another level of sociocultural shame. As a boy, Tayo "remembered how the white men... had pointed at him. They had elbowed each other and winked. He never forgot that, and finally, years later, he understood what it was about white men and Indian women: the disgrace of Indian women who went with them" (57). Within the Laguna, the disgrace and shame was for the Indian girl who gets engaged in a relation with a white man unlike the sense of victory in case it was an Indian man who got into a relation with a white woman. This is what Tayo "during the war... learned about white women and Indian men" (57) as he started telling his sexual conquers to his friends for their delight and cheering. What he did not realize was that even his mother was suffering from a similar ordeal: "She hated the people at home when white people talked about their peculiarities; but she always hated herself more because... she knew their pain at what she was doing with her life. The feelings of shame at her own people and at the white people, grew inside her, side by side like monstrous twins" (69).

Tayo faced what we can call a color crisis. As a half breed he was partially white. That is why he was hated by the reservation's citizens like Emo who "hated him since the time they had been in grade school together, and the only reason for this hate was that Tayo was part white" (57). On the other hand, during the war, he was ordered to kill the Japs who are just as white as one of his parents and as white as the white Americans who gave the order and who despise him for being a colored American but are not really so different from him or his colored Laguna people who despise him as well for his half-breed origin as a son of a colored mother and a white father. This tightly knitted web of 
Bearing the Burden to Neverland: Exorcising Demons of Otherness with Healing Incantations of Magical Realism in Leslie Marmon Silko's Ceremony, Gloria Naylor's Bailey's Café and Laura Esquivel's Like Water for Chocolate.

tangled color prejudices surfaced with the sight of the corpses of the dead Japanese soldiers whom he was ordered to kill but could not:

That was the first time Tayo had realized that the man's skin was not much different from his own. The skin. He saw the skin of the corpses again and again...even white men were darker after death. There was no difference when they were swollen and covered with flies. That had become the worst thing for Tayo: they looked too familiar even when they were alive. (7)

The Japanese are white. The other Americans who despised him were white. He was despised because he was not white. He was also despised by the Laguna citizens because he was partially white. But he was ordered to kill white people. And the order came from white people because those other white people were not Americans. But he is an American. But he is still despised because he is not considered by the other white Americans a real American and he is supposed to join a war and defend a country whose people do not consider him one of them.

But Silko argues the other way round. According to Silko, the problem is not

Tayo's, it is the others'. The world she recreates in the novel suggests that the world we live in is not the real world. It is a mere byproduct of witchery activities and games that changed the nature of the world from a harmonious loving entity to a fearful colliding one. This is what the medicine man explained that Tayo's feelings towards the Japanese soldiers were normal since "[T] hirty thousand years ago they were not strangers" (125). In the novel, Tayo became required to fulfill his quest for healing through the assigned rituals through a world which Betonie drew for him: the stars (the timing), the spotted cattle (the mission), the mountain (the place) and the woman (the partner) (152). His mission is an ongoing mission that "has been going on for a long long time now" (152).

In Bailey's Café, on the other hand, we are introduced to another world. It is a world of women's solidarity in which various images of women who as Kathleen

M. Puhr describes, are "unusual women-women with the power to heal" (519). This comes as a second mechanism of surviving discrimination and abuse. The first mechanism being Silko's recipe of 'remembering' one's identity, one's history and roots as a means of finding a route to sanity and peace, Naylor's mechanism is comprised of 


\section{Dr. Rasha Mohamed Wagdy M. Elleithy}

'forgetting' what has been while Esquivel's is 'forgetting' the pain, remembering one's capacity to achieve a magical world of eternal bliss. Through Eve's hostel, all women have a sanctuary and an asylum for healing and acceptance. Just like Bailey's Café that is there whenever you need it, and wherever you need it since "you can find Bailey's Café in any town" (112), so is Eve's hostel that is supposed to be an area of healing, self-acceptance and renovation. He describes Bailey's location and neighborhood as a magical existence in a timeless universal location: "When I walk out of this cafe and leave this street, I'm still in San Francisco. [Gabe is] up in the Caucasus Mountains. And Eve is in New Orleans. You see, it's whatever life we've come from" (222-23). As Rebecca S. Wood points out, "customers arrive from all over the United States, and from other parts of the world, but unlike with traditional eateries, the customer does not go to the cafe; the cafe goes to the customer: Sadie finds the cafe in Chicago, Jesse in New York, Stanley in Pittsburgh, and Mariam in Addis Ababa, Ethiopia" (384). She thus identifies Bailey's territorial relation with Eve's hostel and Gab's pawnshop as existing in a "Bermuda Triangle of suffering" (384). It is truly a Bermuda triangle since not everyone enters the café finds the healing the need. Sometimes they just fall out to the black hole on the other side of the café.

Early on in the novel, we are introduced to two characters who are supposedly on two ends: a nun and a pimp. Both are an extreme image of dealing with sexuality. It's clear that Naylor's representation of them back-to-back is to show that they are both somehow two faces of the same coin: a coin that represents an extreme perspective on sexuality, femininity and womanhood. Through abstention from or trading of sex, they both represent an extreme attitude in dealing with such a natural human instinct, and thus, Naylor's statement "[S]ister

Carrie and Sugar Man aren't as far apart as they sound. If you listen below the surface, they are both one note player" (33). Sister Carrie represents the conservative eye of a society that is disgusted and afraid of all the types of women coming to the café: "Lord Jesus, it don't make a bit of sense, all this riffraff and scum in here. I can barely swallow my food looking at the likes of them" (32). She is however not presented by Naylor as a chaste woman as much as she is "a woman afraid of her own appetite" (33) which explains her presence in the café in which no one is present except if he needs to be there. Her obsession with sex is expressed through being the opposite of those ladies. It's an obsession through abstention. She keeps preoccupied with the matter to the extent that 'to hear her reading, you'd think loose women were the only thing ever on the Lord's mind" (134). On the other hand, Sugar 
Bearing the Burden to Neverland: Exorcising Demons of Otherness with Healing Incantations of Magical Realism in Leslie Marmon Silko's Ceremony, Gloria Naylor's Bailey's Café and Laura Esquivel's Like Water for Chocolate.

Man, the pimp justified his job as being a protector of the women who work for him. Rather than being considered an exploiter and a predator himself, he states "five of my sisters sitting on gold. They were gonna sell it anyway. I just knew the highest rollers" (34). He does not think poorly of women, according to his logic. On the contrary, he believes "women aren't made up to handle the streets... Women need pretty things around them" (34). Its men, he thinks, are the one who are untrustworthy, "most men aren't worth shit and will take advantage if they get half a chance" (34) and this is where his role comes.

Abused, terrified and lost women who seek peace include Sadie who had a horrible childhood and had to marry a guy old enough to be her dad to escape all the misery. After living with him for twenty-five years she had to work as a prostitute to keep her house. When she finally finds someone who is able to see beyond the obvious, who saw in her eyes "the eyes of a four-year-old dreaming to survive" (70), she could not accept his love. There is also "sweet Esther" (94) who was, as young as 12 years old, given by her own brother to his boss to sexually molest and abuse. She had to follow what can be called the code of silence' of woman who had to suffer in silence "we won't speak about this, Esther" (96). She had to tolerate this torture, being sexually molested by an old guy in the dark cellar for twelve years, to be considered "a good girl" (97). Not only did she fail to speak to save herself. She also failed in speaking or even "killing this man... I thought about sparing the other young girls waiting in line to sleep alone in his pink- and-lace bed" (99). There are the two Marys. The first Mary who was so beautiful that she was sexually abused by strangers and relatives alike as early as when she was nine years old. The abuse continued as she grew older until she decided to deform her own face by a beer opener cutting it ruthlessly to rid herself from the burden of her beauty (111). The other Mary is a fourteen years old pregnant girl who swears none has ever touched her (143). As she was slow-witted, and since there were

"many other virgins to choose from" (152), her mother decided to have "the midwives close her up that tightly. It raises a woman's value" (152) in order to find herself a decent husband. Nevertheless, she gets pregnant and keeps swearing that no one has ever touched her. Then we meet Jesse Bell, a heterosexual who marries into a much richer family. She became an addict as she witnessed her own son becoming detached from her despising her and her family. Being captured using heroine, 


\section{Dr. Rasha Mohamed Wagdy M. Elleithy}

her story became a public scandal that destroyed her marriage and her life. There is also Miss Maple, who is a man addressed as a woman because he is a cross-dresser and whose decision to do so carries deep psychological implications and reasons. As a PhD holder from one of the top universities in the United States, he kept applying for vacancies all over the country. The disappointment was astounding as he was rejected while finding at many times the vacancy still existed adding in the ad that applicants should be 'white'.

Eve herself is a victim of sexism presented as a well-dressed woman with dirt on her fingers. When she explains this, she says that for "a thousand years... I can't wash it off" (82). As a little girl, she was severely punished after being caught by her godfather having an intimate relation with a boy. The metaphor is clear but she makes sure it is emphasized: "there's something that makes you believe you can wash away dirt. But it's not a part of me-it's me” (82). It is shame. Shame that escorts women who justify the injustices and the abuse they had to go through because of their 'dirt'. As Sonja Plesset states in a study she conducted on intimate partner violence:

I learned that the shame they experienced was shaped by two distinct emotions: the embarrassment that comes from submitting to mistreatment in a time and place where women are expected to stand up for themselves and the fear that comes from wondering whether the violence they experienced could be retribution for their failure to adequately - and simultaneously - perform the roles of wife, mother, and lover. (431)

Eve's dirt is an innate feeling of shame for her failure to perform her role as a daughter. Although it takes two to perform any act of intimacy or a sexual encounter, only she had to carry the burden and the shame of doing so. In all her strength and pursuit to build an asylum for likewise abused women, she was unable to heal herself from the pain and shame of what happened.

It becomes clear through this overview of Naylor's central characters and their stories, that they do not represent a wide choice that covers different categories and types of women's subjugation. In fact, the women are all a variation on one type of females-abuse that led to prostitution. Dorothea Buehler argues that "Placing a shattered whore-virgin dichotomy at the center of her work, the African American novelist Gloria Naylor offers an ambivalent portrayal of a black community that challenges the prevalent cultural location of female sexuality within a white patriarchal society" (425) Throughout the history of African American slavery and abuse, black women were the weakest and most terrorized victims. As slavery assumed the 
Bearing the Burden to Neverland: Exorcising Demons of Otherness with Healing Incantations of Magical Realism in Leslie Marmon Silko's Ceremony, Gloria Naylor's Bailey's Café and Laura Esquivel's Like Water for Chocolate.

ownership of the black woman's body, sexual exploitation was a deep and large part of her oppression. As Buehler argues, "Biologically fabricating all black women in this way as sexually aggressive- even hypersexual-beings provided a powerful rationale that paradoxically justified not only the sexual assaults by white slave owners, but also the increased fertility rate which worked to the slave owner's advantage as well" (428). Even after the abolition of slavery, portrayals of black women as voracious within the white American discourse was only a means of justifying her abuse as deserving of what happens to her for "black women to succumb to dichotomous images that oscillate somewhere between good-natured, submissive 'mammies' and hot blooded, sex-crazed, and vengeful jezebels" (428). Thus, Naylor offers a place, a space and a voice to those most voiceless of the African American heritage. By doing so, she is not only attempting to justify or explain their stories. She rather chooses the most socially tabooed and forbidden images to revolt against a mainstream white patriarchal culture and a black patriarchal culture that disagreed on almost everything except the oppression and abuse of black women.

The voice she gives her characters is nonetheless a suffocating stifling tired voice. They do not actually speak. Nadine, the most accomplished and 'happiest' of all the women in Bailey's Café, does not speak, does not smile, and does not laugh. Sadie's only sentence in her own story, is "[A] little tea, please" (39).

Having been abused since childhood, she "discovered ways to make absolutely no noise" (43). In the beginning of her marriage, her first and longest conversation with her husband "took all of five minutes, but it was all about the longest one they would have during their entire marriage" (51) of twenty-five years. Esther, a sex slave to a white master is not allowed to complain or speak for twelve years as repeatedly instructed "we won't speak about this, Esther" (95-9). The second Mary, or Mariam, the slow-witted Ethiopian Jewish girl who became at 14 years old pregnant in spite of being tightly circumcised, cannot speak about how she conceived. She can only say insistently that none has ever touched her. (152) Just like Philomena whose tongue was cut but had her tapestry to speak for her story, Naylor cut her women's tongues off but made their name tags speak for their stories. Whereas Eve symbolizes the first female, the mother and the care taker who nonetheless could not escape abuse and chastity slamming, Mary and 


\section{Dr. Rasha Mohamed Wagdy M. Elleithy}

Mariam are also condemned while carrying the name of the alpha virgin of humanity,

Virgin Mary. Anthony Swindell studies Naylor's use of "biblical stories as source texts" (395) pointing out other biblical allusions including Sadie being the biblical Sarah, "Esther, Esther, Mary (Take One)/ Mary Magdalene, Jesse Bell/Jezebel"

(400). As Swindell points out referring to Amy Benson Brown's close study of rewriting biblical stories to reach a conclusion;

Bailey's Café amounts to a systematic reformulation of the biblical stories which she handles, offering Eve as the restored Earth Mother of a conjectured pre-Genesis matriarchal form of religiosity, Esther as the victim of racial prejudice, Jezebel as a bi-sexual wife, faithful to her husband and female partner, and the two Marys as the site of the crisis of the virgin/ whore dichotomised identity foisted upon them by patriarchy. The hope lies in the Christ-like healing which Eve extends to the female victims of abuse in her alternative version of Eden. For Brown, Naylor has gone beyond the hermeneutics of suspicion into the realm of the hermeneutics of desire, a positive attempt to re-signify the sacred texts of western civilisation, using Bakhtinian techniques to hi-jack the language of the oppressor. (402)

In an attempt to dig the Judeo-Christian Western Culture to find salvation and support for her women, Naylor assimilates her fallen ravished women to biblical figures. By borrowing their names, and retelling their stories, she borrows their sanctity to attract empathy and understanding for their flaws. Rather than humanizing religious figures, she divinizes those human figures that are brought up, in spite of their past and present status, to the highest levels of chastity, innocence and justified deviation. These women are brought against three representative male figures. The three central males in the novel are carrying superficial names be it Bailey, the café owner, or Sugar Man, the pimp, or Miss Maple, the cross-dresser. These names refer to more than a bunch of men. Although they have fake names and appear marginal to the mainstream narrative, they are in fact in the narrative, as in life, indispensable. While Naylor had managed to make this sisterhood of victims from women, the fact remains that they can never completely exist and survive in a world free of men. There will always be the pimp that wants to exploit her, sees in her an opportunity for physical pleasure and profit, a Bailey who is willing to serve and help her and then someone who is willing to go as far as being united to her in her agony and suffering like 
Bearing the Burden to Neverland: Exorcising Demons of Otherness with Healing Incantations of Magical Realism in Leslie Marmon Silko's Ceremony, Gloria Naylor's Bailey's Café and Laura Esquivel's Like Water for Chocolate.

Miss Maple who wears women's clothes and thus literally stand in her shoes.

In fact, Miss Maple, or Stanley, does not suffer from any sexual oppression. Inspired by an incident that took place when he was a little boy, and instead of using cross-dressing as a form shaming, he is now taking on this looks as a form of protest and revolt against the white man's misogynist racist discourse. As Buehler puts it, "[B]y wearing both the emblems of masculinity and femininity on the outside, Miss Maple becomes on one level an androgynous being, who acts in nonsexualized territory and is no longer enslaved in gender-specific clichés" (444). Not only gender-specific clichés. Moreover, with Miss Maple introduced towards the end of the novel, Naylor is attempting to eliminate all traces of the white American stereotypical culture. In a culture where whites are favored over blacks and men over women, by introducing a black male choosing to dress in a woman's clothes not due to a sexual inclination but because he can, "I wear these clothes because I can" (179), she is both screaming an outcry against fake and phony stereotypes that suppress and discriminate, as well as forming a coalition within the African American clan for empathy and alliance. She finds a way of supporting her women through creating a common enemy, White American discriminatory culture, and one identity Black sexless culture in which superficial sexist differences are only a source of pain and fracture.

All of this narrative is made against a background of music. Naylor is giving the reader a transformative experience in which all the social and cultural regulation and taboos are revisited. Chastity, innocence and sanctity do not hold the same implications after reading the novel neither are whoredom, contamination and impurity. Women are the most fragile and the most unbreakable creatures and they are assigned the mission of preserving the human race through biological and social responsibilities. This makes them both, the most vulnerable and the most powerful, in order to perform their role. Between these two extremes, they stumble, suffer and rise. And while reading the novel, more than reestablishing cultural and social norms, self-discovery and understanding is at hand. With such a heavy meal of lessons and discoveries, and just like any clever host setting the meal for her readers through this journey, Naylor does this against a background of music. Not any music, a music that is distinctively African: The Jazz. In fact, the whole novel is structured as one long Jazz note. As Swindell points 


\section{Dr. Rasha Mohamed Wagdy M. Elleithy}

out, "central to the ethos of the novel is the tradition of the blues in African-American music, signaled by the chapter-headings, 'Maestro, if you please', 'the Vamp', 'the Jam',

'Miss Maple's blues', and finally, 'the Wrap'” (401). The blues, this musical genre, as Sylvie Chavanelle points out, is a bridge between musicians and writers, and "must be an attempt at understanding the Other, an antidote to alienation. Naylor's work, through its balance of pathos and joy, cries out the desires of the outcasts, their fierce stoicism, and projects the belief in a victory. Her poetic act is inseparable from the call for recognition on behalf of her brothers and sisters" (400).

While Naylor sets her magical story in a food serving place with a background of music, Esquivel serves the story as the food for the reader where the story is given within a cookbook and her recipes are knitted in a literary narrative, all put in a blender of magic and charm. In doing so, Esquivel ties two of the strongest feminine skills: storytelling and cooking. Both actions of creativity and expression, Esquivel appeals to the readers' five senses, and their six sense as well. In doing so, she prepares the reader to recognize her intention in confronting some of the oldest stereotypes of women: women are weak fragile sobbing creatures, women are born to cook and a woman's greatest achievement is to serve the family and marry. She does not only present these stereotypical images of women within the story. She furthermore exaggerates, mocks and criticizes these images with the help of the technique of magical realism.

Esquivel in the beginning of the novel ties crying with Tita or women in general evoking a well-known stereotype, that of women who are usually described by men as crying "for no reason at all" as she describes Tita's crying. As she does throughout the novel, she mocks stereotypes not through neglect or dismissal but rather through emphasis and highlighting. The reason for women's crying-which is due to their passionate natures as mothers and the caretakers of the families—is described as something incomprehensible but still " a source of entertainment" (7).

Another stereotype is that women are born to cook-a notion that feminists usually reject and challenge. However, Esquivel instead takes this notion a bit deeper and further. Tita is not born to cook-only. She is moreover born inside the kitchen, on the kitchen table: "Tita made her entrance into this world...right there on the kitchen table" (5-6). Cooking, chopping onions, serving food; these usually inacceptable and considered humiliating and degrading tasks, are actually a sort of magic. The spectacle of the "dazzling display made by dancing water drops drippled on a red hot griddle" (8), is such a magical and 
Bearing the Burden to Neverland: Exorcising Demons of Otherness with Healing Incantations of Magical Realism in Leslie Marmon Silko's Ceremony, Gloria Naylor's Bailey's Café and Laura Esquivel's Like Water for Chocolate.

attractive spectacle to the extent that her two sisters who previously thought of the kitchen as "foolish and dangerous", were so attracted to follow her to that extent that one of the sisters touched the hot grill with her bare hands.

The third stereotype is that of women being born to eventually get married and take care of the family. However, in Like Water for Chocolate, these two seemingly concurrent values-marriage and taking care of the family - conflict. Although a girl's family traditionally consider marriage as a girl's highest achievement, Esquivel here uncovers society's relation to women that is summarized in a bunch of burdens that are placed on the shoulders of women. Women thus fall victim to a system of set rules that give authority and power to family members based on their location in a hierarchy of societal obligations and their dedication to implementing them. Consequently, the mother and the motherin-law have more authority than the husband and wife, the husband has more authority than the wife, the wife has more authority than the children, the son has more authority than the daughter...etc. This hierarchy of societal obligations is set on a preferences approach in which certain tasks are given preference over the other: taking care of parents over marriage, marriage over motherhood (an unmarried mother is more disrespectable than a childless wife), motherhood over sterility ( a married woman has to conceive), healthy and well-bred children over deformed or rude children (the conception of a healthy child and the upbringing of the children is the responsibility of the woman-of course), successfully married daughters and sons over offspring bachelorism, daughters with grandchildren over sterile ones, and the list goes on and on and on. A woman's inability to fulfill her role based on her location in the hierarchy of societal obligations to preserve the traditions of society would place a stigma of carelessness, incompetence, failure and even crookedness on her forever.

In the novel, Tita is placed in the middle of a conflict between two societal obligations. Tita cannot get married because she has to take care of her mother: "if he intends to ask for your hand, tell him not to bother. He'll be wasting his time and mine too... being the youngest daughter means you have to take care of me until I die" (10). In this case, the mother's authority over the daughter has to rule. She thus decides to marry Tita's lover and suitor to her older sister since she is the one who is "one hundred percent available and ready for marriage" 


\section{Dr. Rasha Mohamed Wagdy M. Elleithy}

(14). The order is given with strictly feminine language: "your ma talks about being ready for marriage like she was dishing up a plate of enchiladas! And the worse thing is, they're completely different! You can't just switch tacos and enchiladas like that!" (14) On the other hand, and despite Pedro's great love for Tita, his vow to her to remain faithful to their love forever, he agrees to marry her sister with a stereotypical manly notion-love is something and marriage is something else.

Answering Nacha's question "so you intend to marry without love?" he answers, "No Papa, I am going to marry with great love, for Tita that will never die" (15).

His previous promise to her that "[I] swear that my love for [you] will last forever"

(18), did not last for a couple of weeks even! However, his declaration made her

"from that night on... love him forever" (18). This generates the stereotypical paradigm of the love triangle of the two sisters fighting over a man. Like Procne, Philomena and Arteus, here we have Pedro, Tita, and Rausara. Pedro is in love with Tita but still decides to continue with his plans to marry her sister justifying his decision with a manly justification "through this marriage I have gained what I really wanted: the chance to be near you, the woman I really love” (38). This triangle is paralleled with another one namely Mama Elena, her husband and her lover, Gertrud's father. In both triangles, both men and women are victims of the societal hierarchy of obligations. However, Esquivel takes this deeper where these societal norms are complicated with ethnic grievances as well.

Food in this novel, just like Ceremony and Bailey's Café, is more than just food for the body. It is moreover a metaphor for the way women are treated.

Capon, which is a kind of chicken that is brought to be castrated, fed and fattened, is a metaphor for the way Tita is being treated by her mother. The castration procedure of the chicken is described in detail: "The castration is made by making an incision over the chicken's testicles, sticking your fingers in to get a hold of them, and pulling them out. After that is done, the wound is sewn up and rubbed with fresh lard or chicken fat" (27). Tita, and by extension all women, identifies herself with the capon. She believes they should have chosen her instead of the capon to castrate, "at least then there would be some justification for not allowing her to marry and giving Rosaura her place beside the man she loved" (27). Forced to cook the wedding banquet for her sister and the man she loves, her tears that dropped while cooking are magical. 
Bearing the Burden to Neverland: Exorcising Demons of Otherness with Healing Incantations of Magical Realism in Leslie Marmon Silko's Ceremony, Gloria Naylor's Bailey's Café and Laura Esquivel's Like Water for Chocolate.

Her tears, out of longing and heartbreak causes her sister to physically suffer immense pain to the extent that Pedro could not touch her for months. Food in the novel is moreover, and as is traditionally portrayed, a way to men's hearts and minds. With her meal made with pink roses that turned red when she clasped them to her chest (48), after eating, Pedro, "it was as if a strange alchemical process had dissolved her entire being in the rose petal sauce... that was the way she entered Pedro's body, hot, voluptuous, perfumed, totally sensuous" (52). Thus, cooking for women is not simply a skill, it is an art. It is a magical creative power. When Tita suffers mentally, she could not remember

"how to cook so much as a couple of eggs, [or] enjoy any kind of food" (124). Food is the art of life. Not only does it feed the body, but made well, made correctly, it feeds the soul as well. Women's tears are a cure rather than a curse.

The first sign of Tita's recovery was her ability to cry again. (125)

Thus, our generous hostesses give their best to entertain their guests. While they blend the charm of storytelling with magic, each one adds her secret ingredient to the recipe. Whereas Silko takes the reader through the wonders of the old Indian myths, Naylor serves food with a distinct musical background, and Esquivel serves magical food and delicious stories. In fact, the connection between food and the three Magical Feminist writers' novels is remarkable. In Ceremony, Silko presents eating as a magical tool to control the eaters. On the mythical level, the Spiderwoman instructed the Sun to find his children-the clouds of the four directions-locked up at the ch'o'yo kaup'ata's or the Gambler's house. The Gambler was able to seduce and control them through a magical meal in which he mixed the cornmeal with human blood. (170-5) It was food that was among the healing tools used to cure Tayo whether by the healer or the one used by Montano Ts'eh served him as a healing incantation that merged him with the world of the supernatural in which the chili "was thick, red like fresh blood, and full of dried corn and fresh venison" (178). In Bailey's Café, as the title clearly suggests, food is central. However, serving food is not what the café is actually about as Bailey declares: "if we start serving them readily they'll begin thinking we are actually in the business of running a cafe" (28). On the other hand, in Like Water for

Chocolate, as Sanchez puts it, "the recipes are both frame and what is framed, bed and embedded narrative, as the whole novel becomes a kind of recipe on how to survive as a woman in a Mexican 


\section{Dr. Rasha Mohamed Wagdy M. Elleithy}

patriarchal society at the beginning of the century" (217). The whole novel is constructed as one big cook book connecting the magical pleasure of eating with the magical pleasure of reading: a feminine recipe for strength and healing. Serving food and telling stories are universally the most efficient womanly/ motherly healing recipe for a broken heart and a wounded ego. Adding a touch of magic to an already magical recipe in its effect and extent of pleasure is only a bonus.

Thus, our generous hostesses give their best to entertain their guests. While they blend the charm of storytelling with magic, each one adds her secret ingredient to the recipe. Whereas Silko takes the reader through the wonders of the old Indian myths, Naylor serves food with a distinct musical background, and Esquivel serves magical food and delicious stories. In fact, the connection between food and the three Magical Feminist writers' novels is remarkable. In Ceremony, Silko presents eating as a magical tool to control the eaters. On the mythical level, the Spiderwoman instructed the Sun to find his children-the clouds of the four directions-locked up at the ch'o'yo kaup'ata's or the Gambler's house. The Gambler was able to seduce and control them through a magical meal in which he mixed the cornmeal with human blood. (170-5) It was food that was among the healing tools used to cure Tayo whether by the healer or the one used by Montano

Ts'eh served him as a healing incantation that merged him with the world of the supernatural in which the chili "was thick, red like fresh blood, and full of dried corn and fresh venison" (178). In Bailey's Café, as the title clearly suggests, food is central. However, serving food is not what the café is actually about as Bailey declares: "if we start serving them readily they'll begin thinking we are actually in the business of running a café" (28). On the other hand, in Like Water for

Chocolate, as Sanchez puts it, "the recipes are both frame and what is framed, bed and embedded narrative, as the whole novel becomes a kind of recipe on how to survive as a woman in a Mexican patriarchal society at the beginning of the century" (217). The whole novel is constructed as one big cook book connecting the magical pleasure of eating with the magical pleasure of reading: a feminine recipe for strength and healing. Serving food and telling stories are universally the most efficient womanly/ motherly healing recipe for a broken heart and a wounded ego. Adding a touch of magic to an already magical recipe in its effect and extent of pleasure is only a bonus.

The three novels discussed here tackle three journeys of healing from the grievances of ethnic, cultural, social and sexual injustices. They reflect the venture of three creative women writers who decided to deal with the burdens of ethnicity and otherness in the most magically 
Bearing the Burden to Neverland: Exorcising Demons of Otherness with Healing Incantations of Magical Realism in Leslie Marmon Silko's Ceremony, Gloria Naylor's Bailey's Café and Laura Esquivel's Like Water for Chocolate.

powerful way. Instead of fighting, whining or grumbling, they decide to gracefully carry the burden to a land of survival and acceptance. The three women writers, of three different ethnic American backgrounds, present the reader with a poignant experience of heartbreak, recovery and rebirth. The protagonist of each novel becomes a phoenix that rises from the ashes of injustices, horror and pain into a powerful beautiful being. In Ceremony, the ceremony is not only a ritual that Tayo undergoes to recover from his guilty conscience and horrific war experience. Silko presents us with a book that becomes itself a ceremony for our catharsis and healing. Ending the novel with a manhunt of Tayo led by Emo and his gang, he is betrayed by his friends Harley and Lorey who decide to give in to Emo's threats and conspire to get Tayo. In doing so, and instead of a peaceful ending of Tayo's healing process, all they want is "change [the end of the story] ... the way all their stories end.... The violence of the struggle excites them, and the killing soothes them." (232-3) However, with their failure to do so, Emo decides to torture and kill them instead. Tayo watches them from afar and returns home to tell the story to his people. He does not try to take vengeance or express anger. This is because he realized the whole image of life. There was a unity among all human beings regardless of their ethnicity, nationality or color:

The lines of cultures and worlds were drawn in flat dark lines on fine light sand, converging in the middle of witchery's final ceremonial sand painting. From that time on, human beings were one clan again, united by the fate the destroyers planned for all of them, for all living things; united by a circle of death that devoured people in cities twelve thousand miles away, victims who had never known these mesas, who had never seen the delicate colors of the rocks which boiled up their slaughter.

He cried the relief he felt at finally seeing the pattern, the way all the stories fit together - the old stories, the war stories, their stories-to become the story that was still being told. He was not crazy; he had never been crazy. He had only seen and heard the world as it was: no boundaries, only transitions through all the distances and time. (246)

There is a unity among all human beings just as there is a unity among the destroyers will always win. They will keep destroying and escape with their crimes: "the FBI called it an accident... I heard he 


\section{Dr. Rasha Mohamed Wagdy M. Elleithy}

went to California" (260). This, too, is part of the universe. This story is eternal, "[I]t seems like I already heard these stories before... only thing is, the names sound different." (260)

In Bailey's Café, a new baby is born. Mariam gives birth to a baby boy whose father is unknown. The association between the name Mariam and Virgin Mary, the fatherless baby boy and Jesus Christ is clear. As Swindell states, Naylor builds the whole novel on a series of associations with Christian allegories.

Naylor's aim is clear. Where Eve is named after the alpha female of the world, Naylor recreates in her asylum a worldly heaven in which women are accepted not as who they currently are but as who they might have been-chaste, pure and uncontaminated-had not they been suffered from social, ethnic and sexual discrimination and oppression. Just as chaste as Virgin Mary was, despite any logical worldly judgement of a woman assumed to have conceived a fatherless baby, God's creatures can also be excused, their actions interpreted on other terms. In Eve's heaven, women learn to forget in order to survive. Their healing process comprises of them forgetting what has been as evil and painful in order to be able to survive:

Anybody ask you who you are?

Who you are?

Who you are?

Anybody ask you who you are?

Tell him-you're the child of God. (224)

In Like Water for Chocolate, the ending is as magical as the whole story. Esquivel uses the stereotypical image of the waiting woman blending it with power and magic. An older generation of oppression, of entertaining meaningless unjust traditions rebel against their reproduction with the next generation. Tita and Pedro, as the reader finds out towards the end of the novel, have had a pact with Rosaura who realized their love for each other is beyond her ability to fight. Consequently, she made a pact with them "to maintain that appearance that her [Rosaura's] marriage was going splendidly, and the most important thing for her was that her daughter grow up within that sacred institution, the family... Pedro and Tita had sworn to be absolutely discreet about their meetings and keep their love a secret." (237) Part of the pact was that Tita gives up having kids and would share

Esperanza, Pedro's and Rosaura's daughter with them. Tita "would be in charge of feeding the child, Rosaura of her education." (237) When the time came and Esperanza was in love, her mother 
Bearing the Burden to Neverland: Exorcising Demons of Otherness with Healing Incantations of Magical Realism in Leslie Marmon Silko's Ceremony, Gloria Naylor's Bailey's Café and Laura Esquivel's Like Water for Chocolate.

fought to reproduce Tita's tragedy by asking for her right to have her daughter staying with her till her death. Tita and Pedro fought this resulting in the death of Rosaura of grief and the marriage of her daughter. Only then, Tita was able to marry Pedro in a magical setting in which their marriage night was the end of their life on earth going where "they left together to the lost Eden. Never again would they be apart." (245)

In classic myths and fairytales, feminine patience and tolerance as an antithesis to free will, independence and revolution are represented as the most rewarding values. In the Odyssey, Penelope's love, patience and dedication is an exemplary attitude for a feminine role model. Penelope, who spent fifteen years unweaving at night what she has knitted during the day to keep away her suitors pledging that she would only take a husband when she finishes her shawl, is not considered stupid or dumb for waiting all these years for her husband Odysseus whose sexual conquests and adventures with other women takes the scope of a book. Snow White is poisoned by another woman who competes with her over the throne of beauty and is only saved by a kiss from her savior prince. Sleeping Beauty was kept asleep for years until her prince came to give her a kiss of life while Cinderella, on the other hand, who is endowed with a magical fairy that would turn pumpkins into chariots, rats into horses and rags into a beautiful dress fails to save her from her step mother with her magic stick. Only a prince can. However, time changes and all and these fairy tales are replaced with new ideals.

Women need themselves, their inner power and belief in their selfworth to be saved. They need each other for support, healing and resurrection. Ideals that are well represented in the newest version of Snow White adapted for the cinema in a blockbuster movie titled Snow White and the Huntsman, Snow White's stepmother does not compete with Snow White over a traditionally feminine ideal and goal-beauty. She actually kills her husband, Snow White's father, on their marriage day avenging her broken heart from other men, gaining power over his land and kingdom. Snow White does not bite the poisoned apple and gets saved by a knightly prince's kiss. After she bites the poisoned apple, she is kissed by a vagabond warrior in love with her. She then leads an army to win back her father's kingdom as the rightful heiress to his throne. This is not to say that women do not need men or do not want them. Chivalry, courage, bravery, nobility, courteousness, boldness and 


\section{Dr. Rasha Mohamed Wagdy M. Elleithy}

virility are manly traits that had melted the hearts and minds of women throughout history in all languages, cultures and locations, and still do. Modern Penelopes are still willing to wait, to strive to prove their loyalty and dedication to the one and only who can lead them into a life of peace and love. However, modern Odysseuses seem to be less skillful in finding their ways home. Disappointment after disappointment, betrayal after betrayal, women decide to control their fates. To do so, they need to carry their burden off their shoulders and move free from the depressions of societal discrimination. As victims of double discrimination as ethnic women with the American Patriarchal White community, they blend pain with passion, storytelling with magic to produce a beautiful account of their battle for healing and survival. 
Bearing the Burden to Neverland: Exorcising Demons of Otherness with Healing Incantations of Magical Realism in Leslie Marmon Silko's Ceremony, Gloria Naylor's Bailey's Café and Laura Esquivel's Like Water for Chocolate.

\section{Works Cited}

Al-Barazenji, Luma Ibrahim. Women's Voice and Images in Folk Tales and Fairy Tales, Proceedings of Socioint14- International Conference on Social Sciences and Humanities, 2014. pp. 144-150

Baxandall, Rosalyn and Linda Gordon. Chapter 24. Second-wave Feminism, pp. 414-430 in A Companion to American Women's History, Nancy A. Hewitt, ed.

Malden, MA: Blackwell, 2002.

Berson. Misha. "Naylor's Made It-- Noted Novelist Passes Apprenticeship with Colorful Bailey's Cafe." The Seattle Times, (24 September 1992).

Blicksilver, Edith. Literature as Social Criticism: The Ethnic Woman Writer, Modern Language Studies, Vol. 5, No. 2 (Autumn, 1975), pp. 46-54.

Bowers, Maggie Ann. Magic(al) Realism: Routledge. 2004.

Buehler, Dorothea. Below the Surface: Female Sexuality in Gloria Naylor's "Bailey's Café". Amerikastudien / American Studies, Vol. 56, No. 3 (2011), pp.

425-448.

Chavanelle, Sylvie Gloria. Naylor's Bailey's Cafe: The Blues and Beyond. American Studies International, Vol. 36, No. 2 (JUNE 1998), pp. 5873.

“Chaos at Fifty.” Physics Today, Vol. 66, No.5/ 27 (2013).

https://doi.org/10.1063/PT.3.1977 Retrieved 30/11/2017.

Eppert, Claudia. Leslie Silko's Ceremony: Rhetorics of Ethical Reading and Composition, Jac, Vol. 24, No.3 (2004), pp. 727- 754.

Faris, Wendy. "The Question of the Other: Cultural Critiques of Magical Realism”. Janus Head, Vol. 5, No. ii (2002), pp. 101-119.

Gladsky, Thomas S., "To You, I Now Have Something of My Very Own to Say: Monica Krawczyk, Victoria Janda and the Voices of the Ethnic Woman Writer", Polish American Studies, Vol. 52, No. 1 (Spring, 1995), pp. 31-41.

Gemberling, Kyra. Feminine Agendas: The Historical Evolution of Feminism as Reflected in the Content of American Women's Magazines. Elon Journal of Undergraduate Research in Communications. Vol. 5, No. 2 (2014), pp. 1-3. Groenewold, Melissa. Chicana Feminism: SelfActualization through Border Conscience, Intercultural Communication Studies. Vol. XIV, No.3 (2005), pp. 92- 100.

Goldstein, Leslie F. "Early Feminist Themes in French Utopian Socialism: The St.-Simonians and Fourier". Journal of the History of Ideas. Vol. 43, No. 1 (1982), pp. 91-108.

Goodrich, Samuel Griswold. The Manners, Customs, Antiquities of the Indians of North and South America: Rand and Mann. 1849. 


\section{Dr. Rasha Mohamed Wagdy M. Elleithy}

Haaken, Janice. Hard Knocks: Domestic Violence and the Psychology of Storytelling: Routledge, 2010.

Hooks, Bell. Feminism Is for Everybody: Passionate Politics: South End Press, 2000.

Krolokke, C., \& Sorensen, A. S. "Three waves of Femeinism." Gender Communication Theories and Analyses: From Silence to Performance: Thousand Oaks, CA: Sage, 2005.

Lorenz, Edward N. "Deterministic Nonperiodic Flow". Journal of the Atmospheric Sciences. Vol. 20, No.2 (March 1963), pp. 130-141. May 22, 2015

Offen, Karen. Defining Feminism: A Comparative Historical Approach. Signs, Vol. 14, No. 1 (autumn, 1988), pp. 119-157.

Plain, Gill and Susan Sellers (ed.) A History of Feminist Literary Criticism. Cambridge University Press. 2007.

Plesset, Sonja. Beyond honor: a new approach to the many sides of shame.

Journal of Modern Italian Studies, Vol. 12, No. 4 (2007), pp. 430-439.

Puhr, Kathleen M. Healers in Gloria Naylor's Fiction. Twentieth Century Literature, Vol. 40, No. 4 (Winter 1994), pp. 518-527.

Rampton, Martha. Four Waves of Feminism. Pacific Magazine. 2015. http://www.pacificu.edu/about-us/news-events/four-waves-Feminism 2015. Retrieved June 22, 2016.

Sanchez, Maria Ruth Noriega. Magic Realism in Contemporary American Women's Fiction. Phd dissertation. 2000.

Moi, Toril. "Feminist, Female, Feminine". The Feminist Reader: Essays in Gender and the Politics of Literary Criticism (Ed. Catherine Belsey and Jane Moore), (2nd Edition): Palgrave Macmillan. May 1997.

Smith, Andrea. American Studies without America: Native Feminisms and the Nation-State. American Quarterly (2008), pp. 309- 315.

Spivak, Gayatri Chakravorty. Can The Subaltern Speak? Post-Colonial Studies Reader (Ed. Bill Ashcroft, Gareth Griffiths and Helen Tiffin) Routledge London and New York. 1995.

Swindell, Anthony. Latecomers: Four Novelists Rewrite the Bible. Biblical Interpretation, Vol. 15 (2007), pp.395-404.

Wells, Kimberly Ann. Screaming, Flying, and Laughing: Magical

Feminism's Witches in Contemporary Film, Television, and Novels. Texas A\&M University. PH. D. Dissertation. 2007.

Wilde, Lady. Ancient Cures, Charms, and Usages of Ireland. Driftwood from Scandinavia. 1890.

Wood, Rebecca S. "Two Warring Ideals in One Dark Body": Universalism and Nationalism in Gloria Naylor's Bailey's Café. African American Review, Vol. 30, No. 3 (autumn, 1996), pp. 381-395.

Zinn, Maxine Baca and Bonnie Thornton Dill. "Chapter One: Difference and Domination". Women of Color in U.S. Society (ed. Maxine Baca Zinn and Bonnie Thornton Dill). Temple University Press, 1994. 


\section{الملخصات بالانغة العربية}

تحدث الصمت: دراسة لصورة المرأة في القصة القصيرة "الهروب" للكاتبة

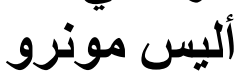

اكتسبت الكاتبة الكندية ألبس مونرو - سيدة القصة القصيرة والحائزة على جائزة نوبل في الأدب

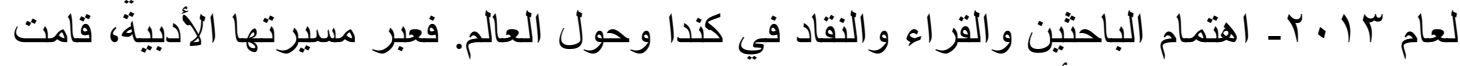

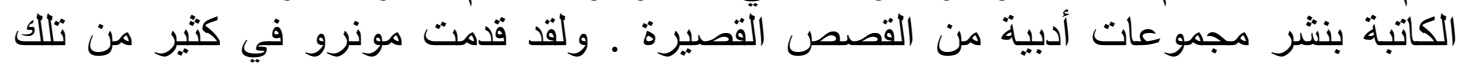

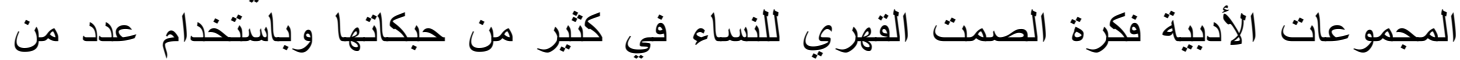

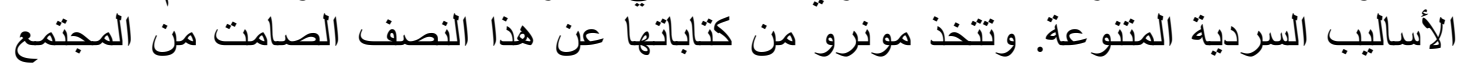

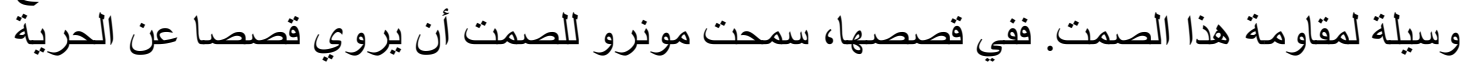
وقهر الذكور و الرغبة في التغيير. وتدرس هذه الورقة البحثية أسباب وصور صدمت صبت بطلاتها في

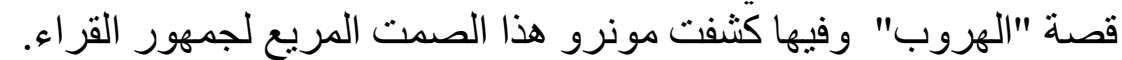
الكلمات المفتاحية: مونرو، الصمت، النسوية، كار لا، القهر، الهوية، لهون، التمييز 


\section{الماخصات بالانغة العربية}

\section{الفعل الاجتماعي للترجمة: العلوم و الفن و الحياة}

الملخص

تهدف هذه الورقة الى إمكانية وجود استر اتيجية مستدامة في مصر من خلال مؤشرات التقييم

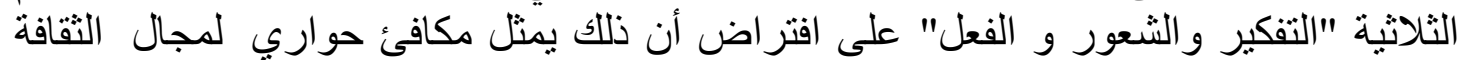

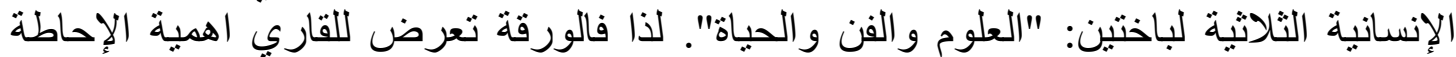

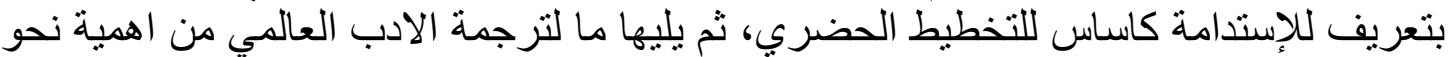

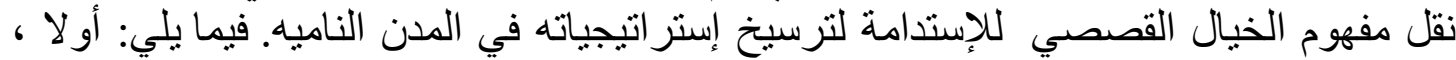

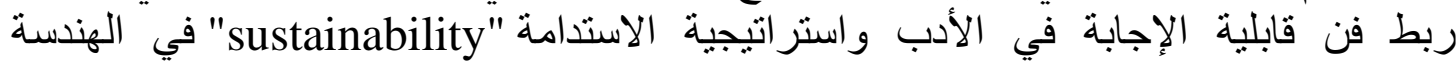

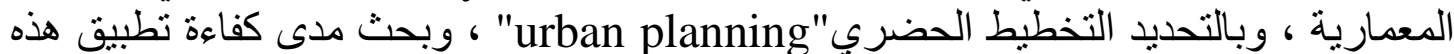
الاستر اتيجية على احد مشروعات بناء الكباري الجاري تشييدها حاليا في مصر. ثانيا ، ربط كيط

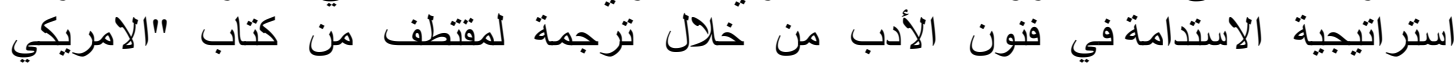
المشاكس"(1909 (1) لاعادة صياغة المدن النامية مثل مصر و تحسين معمارمبانيها لذا اتت

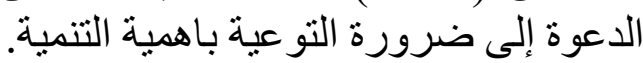
الكلمات المفتاحية : الفن، التغيير ، الترجمة ، التربة ، التنمية والأدب، ومصر المستدامة ، والترجمة الاجتماعية 


\section{الملخصات بالالغة العربية}

قراعة في الصورة الشرق آسيوية الكندية الجديدة لتجربة المهاجرين والإصلاح

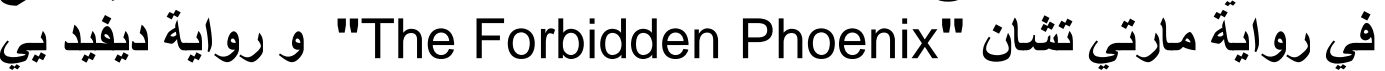
"صاحبة الرداء الأحمر" من خلال نظرية السيمائية

$$
\begin{aligned}
& \text { مقدمة من رانيا محمد رفيق عبد الأنتاح خليل }
\end{aligned}
$$

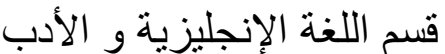

$$
\begin{aligned}
& \text { كلية الآداب و الإنسانيات بالجامعة البريطانية في مصر الإبل }
\end{aligned}
$$

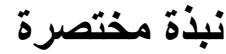

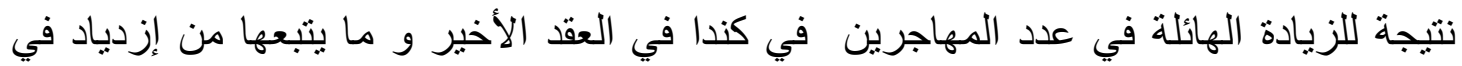

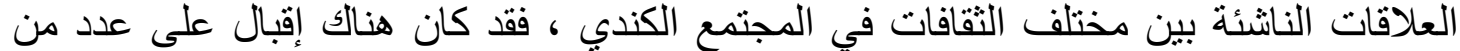

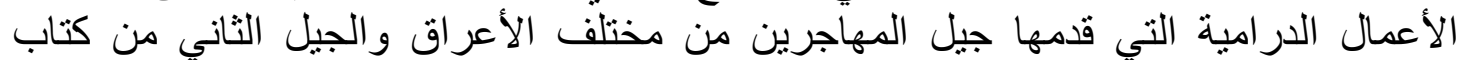

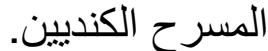
تتتاول هذه الورقة البحثية تحليلا للصورة الثرق آسيوية الكندية الجديدة لتجربة المهاجرين

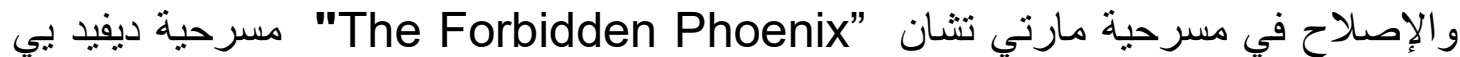

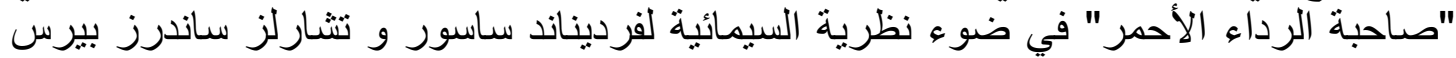

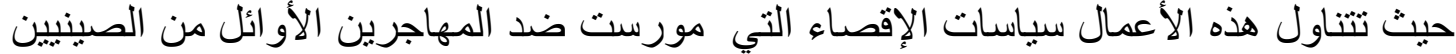

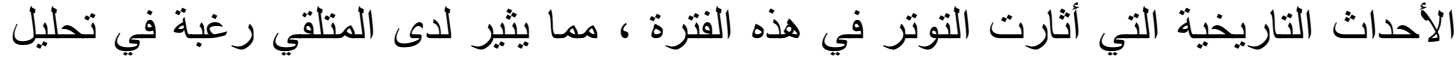

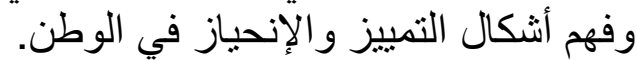

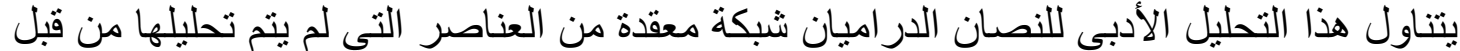

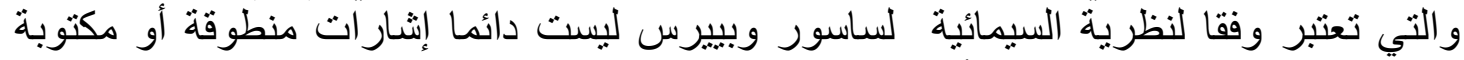

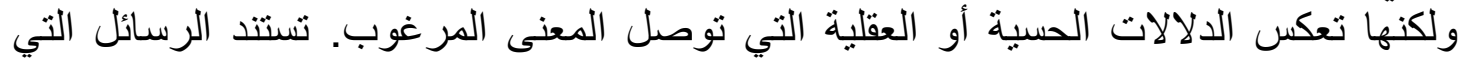

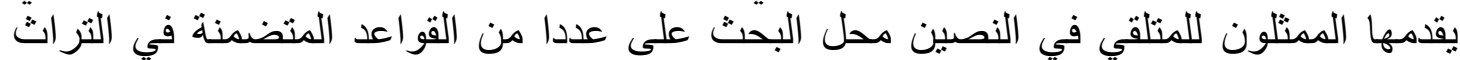

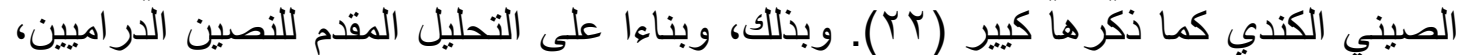

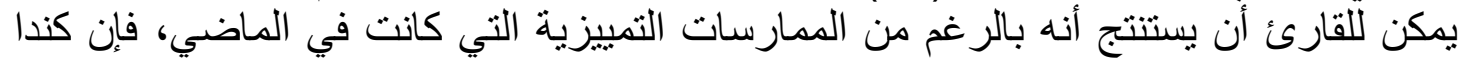

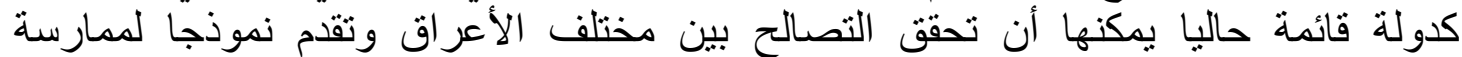

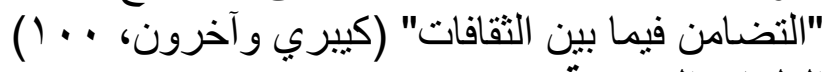

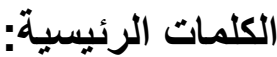
المسرح الثرق آسيوي الكندي، نظرية السيمائية، تجارب المهاجرين، الإصلاح، دراما السكك

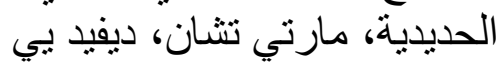




\title{
الملخصات باللفة العربية
}

\section{الواقعية السحرية: خطوة أخرى نحو النسوية البيئية}

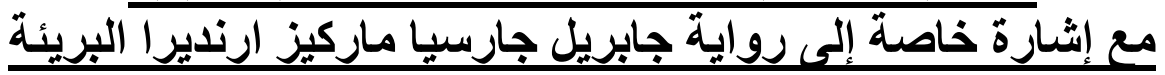

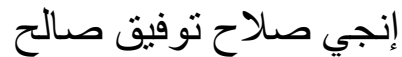 \\ مدرس ـ كلية الآداب ، جامعة دمياط
}

تلهدف الورقة البحثية إلى التحقق من مساهمة الواقعية السحرية كأسلوب سردي للمحتوى النقدي

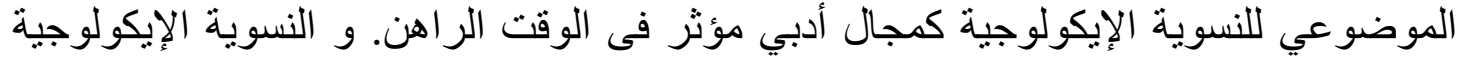

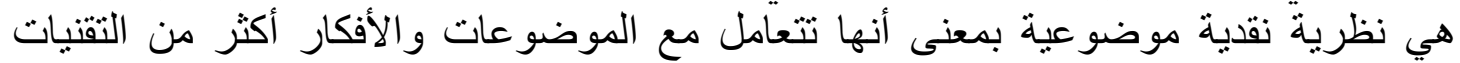

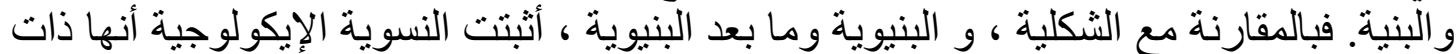

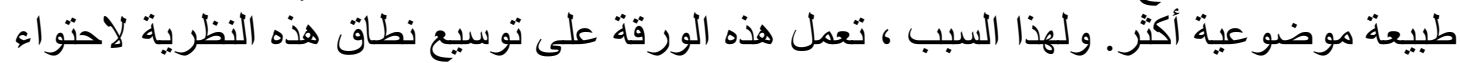

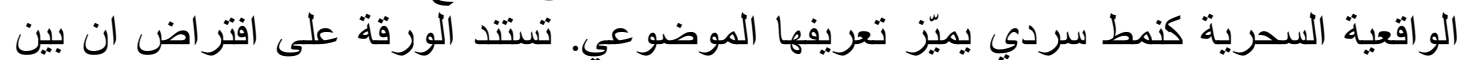

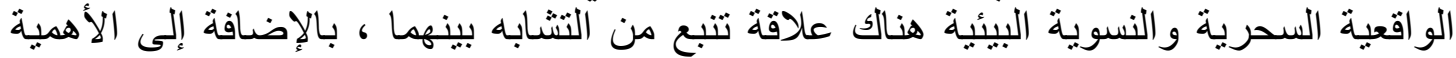

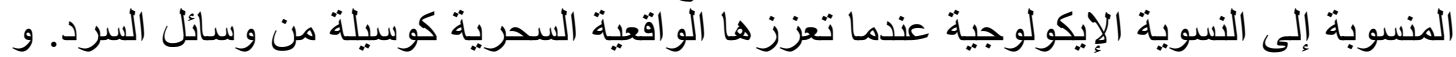
تشير الورقة الى مفهومى "الازدواجية" و "اللامركزية السردية" كمصطلحات قيادية ترية تربط كل

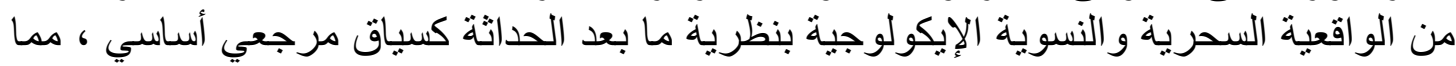
يجسد فكرة قبول "الآخر". وفى سياق البحث يتم الاشارة الى رواية جارسيا ماركيز القصة

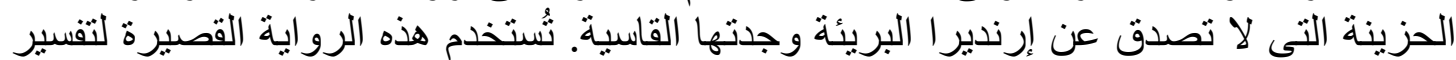

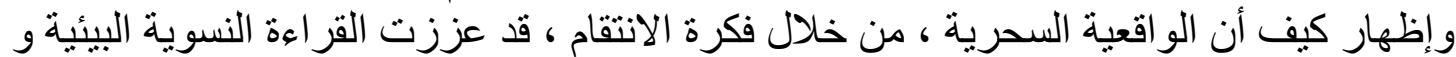

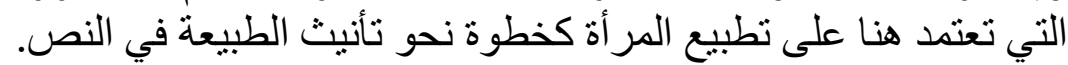
كلمَّات مفتاحية: تعند

الو اقعية السحريةـ اللامركزية السرديةـ النسوية البيئيةـ تأنيث الطبيعةـ رواية ماركيز ارنديرا البريئة 


\section{الملخصات بالاغة العربية}

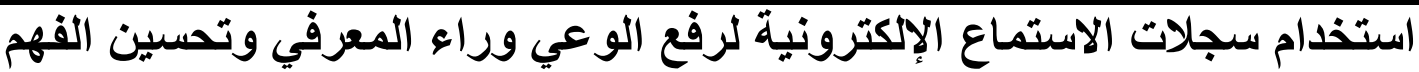

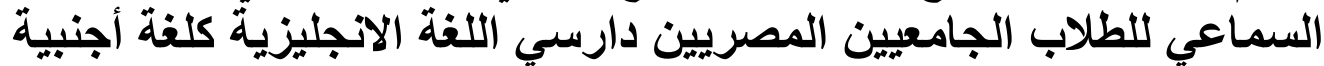

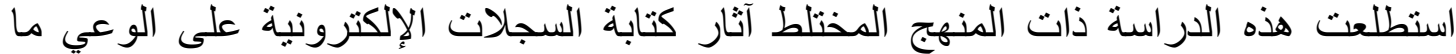

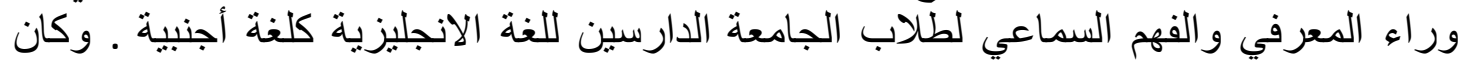
عدد المشاركين • V طالبا من الفرقة الثانية تخصص اللغة الإنجليزية في جامعة الوادي الجديد

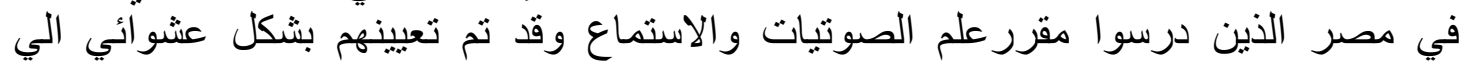
مجمو عة ضابطة (36) ومجمو عة تجريبية (34). بينما تلقت المجمو عتان تعليمات في الصف

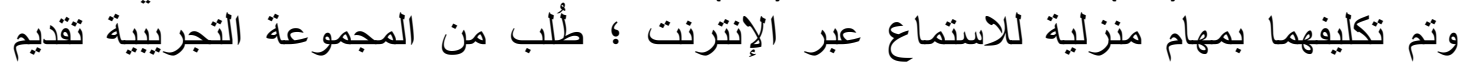

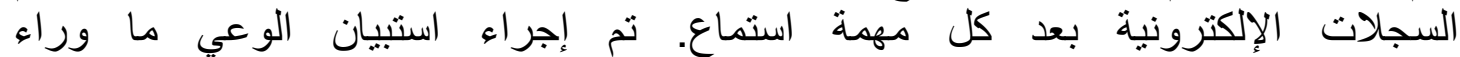

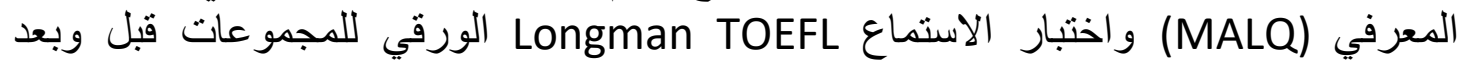
التجربة. وقد أظهر تحليل نتائج الاختبار البعدي للاستماع أن المجموعة التجريبية تفوقت بشكل

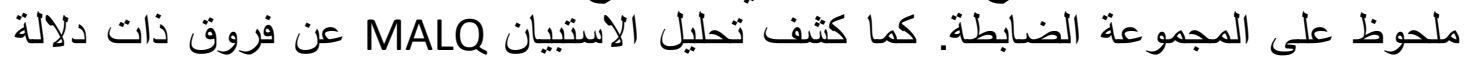

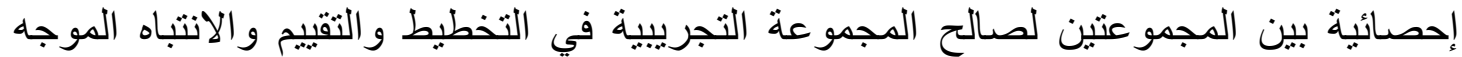

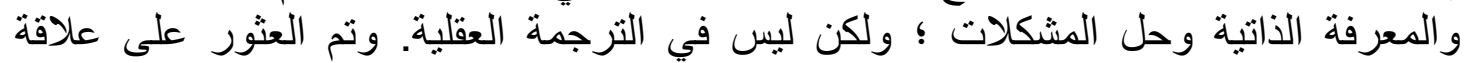
إيجابية بين الوعي ما وراء المعرفي والفهم السماعي. كما وجد أن المستمعين ذوي التوني الكفاءة

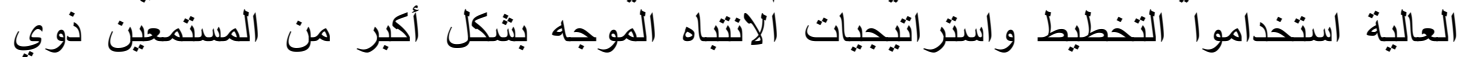
الكفاءات المنخفضة بينما استخدم المستمعون ذوي الكفاءة العالية الترجمة الذهنية بنسبة أقل من

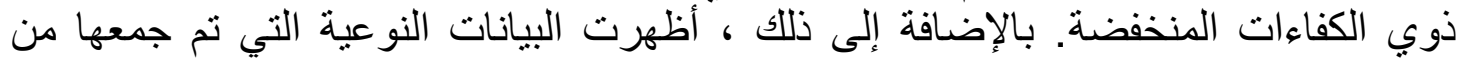

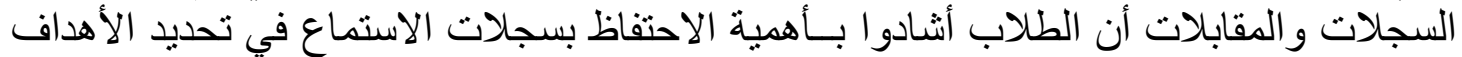

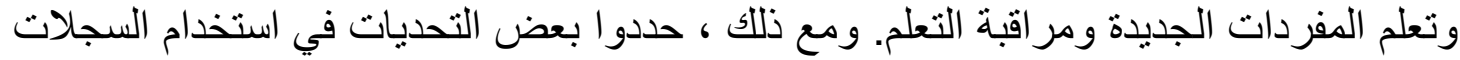
مثل تضييع الوقت وصعوبة التفكير في عملية الاستماع. وقدمت الدات واسة بعضة بعض التطبيقات و التوصيات للأبحاث المستقبلية.

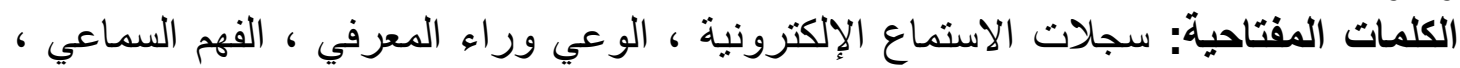
طلاب الجامعة دارسي اللغة الانجليزية كلغة أجنبية ، المنهج المئهي ، المختلط. 


\section{الملخصات باللفة العربية}

\section{نظرية الخداع الشخصي: تحليل لغوي-معرفي لسورة يوسف}

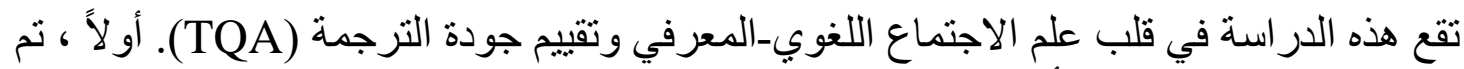

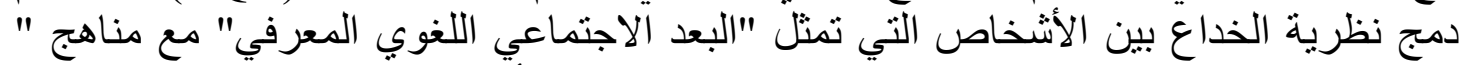

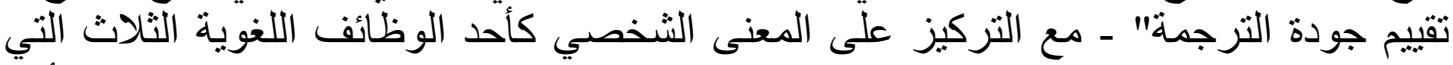

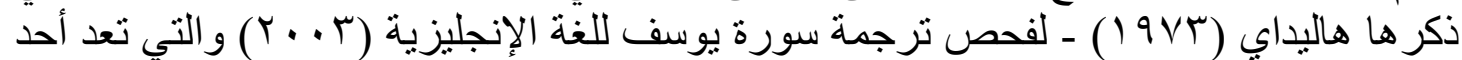

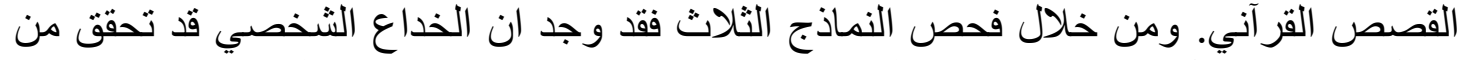

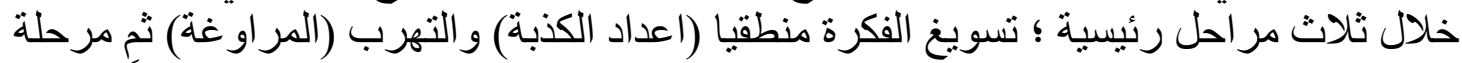

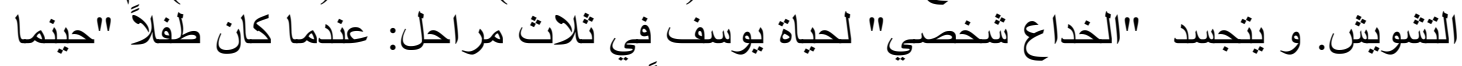

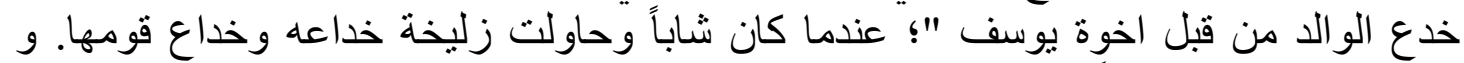

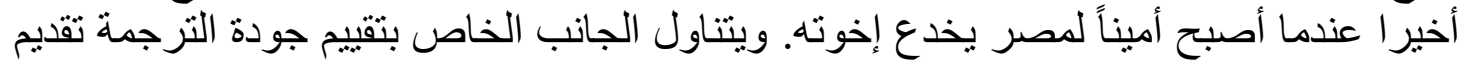

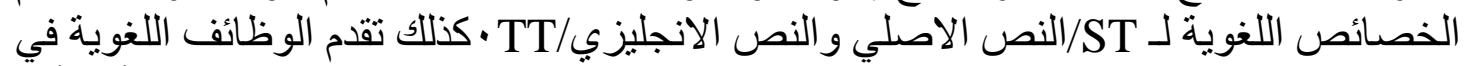

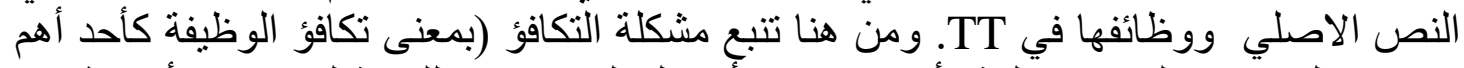

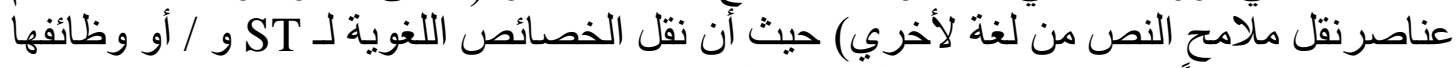

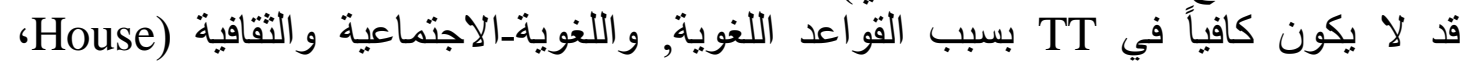

الكلمات الدالة: التكافؤ الوظيفي, تقييم جودة الترجمة, التواصل بين الأشخاص, نظرية الخداع الثخصي. 


\section{الملخصات بالالغة العربية}

تمثيل الأطراف الأجتماعية الفاعلة في الخطاب البرلماني لجاسيندا أرديرن : تحليل في ضوء

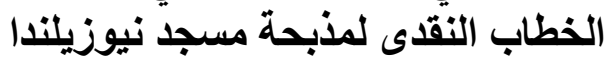

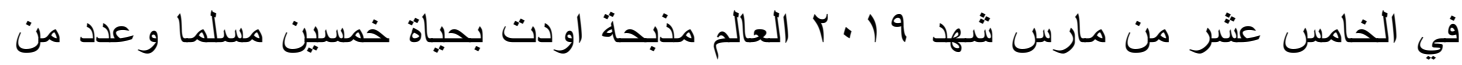

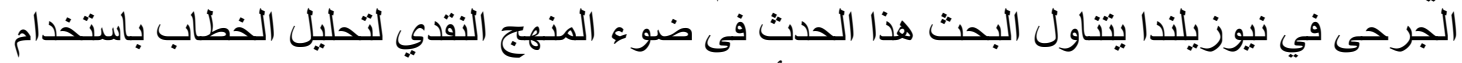

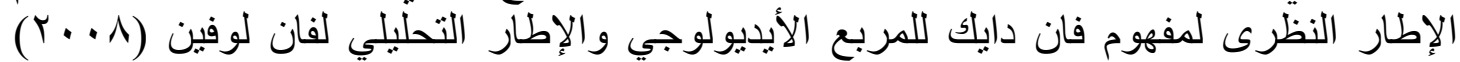

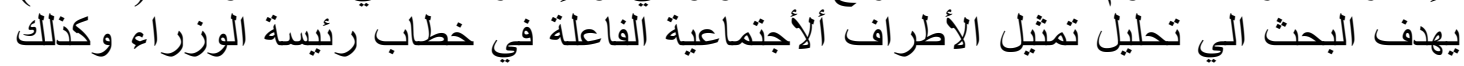

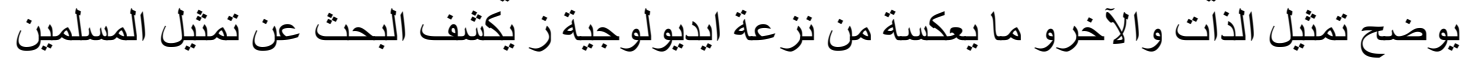

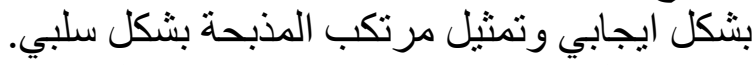

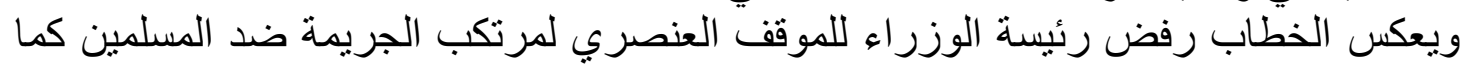
يعكس سياسة تقبل الآخر 


\section{الملخصات بالانة العربية}

\section{تلدريس المشاركة المدنية من خلال الأدب \\ أ.د. غادة عبد الحفيظ}

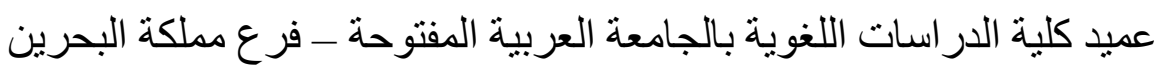

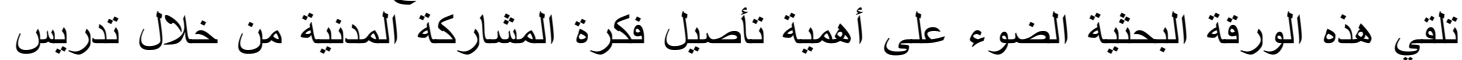

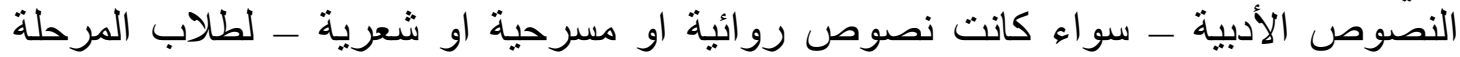

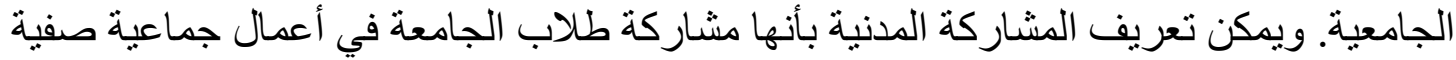

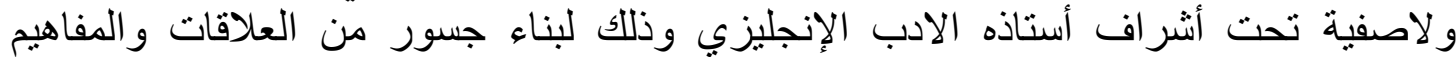

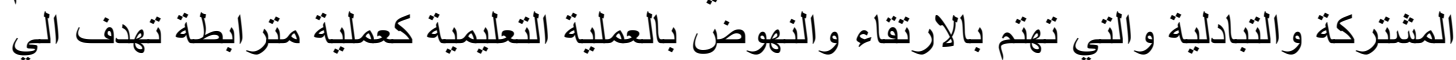

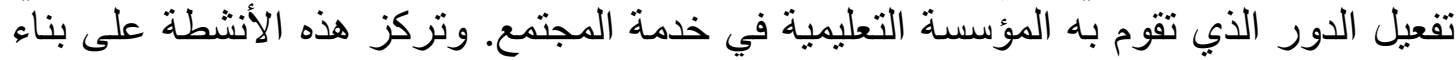

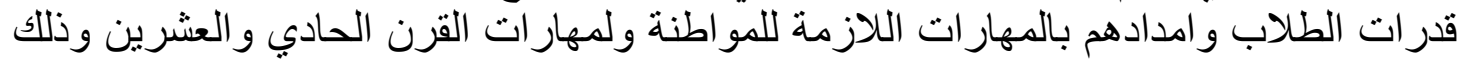

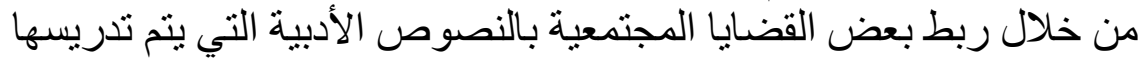

ومن الجدير بالذكر أن قراءة وتحليل النصوص الأدبية لا تزيد فقط من وعي الطلاب بالعديد من

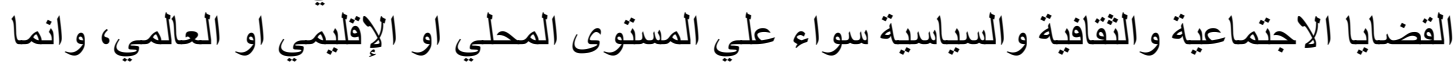

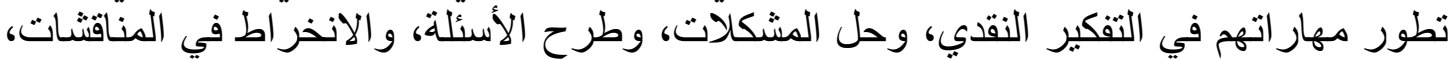

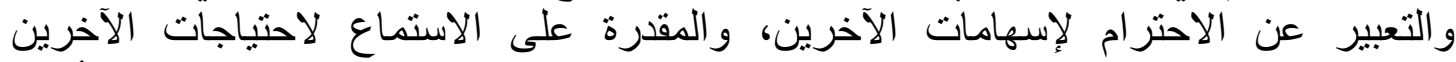
وظروفهم، ومهار ات التفاوض و غير ها من المهار ات الحياتية المطلوبة في سوق العمل وأيضا لأنا مهار ات المو اطنة ولتعزيز مشاركة الطلاب المدنية تقترح الباحثة ضرورة خلقة بئئة صفية تمتاز بالديمقر اطية

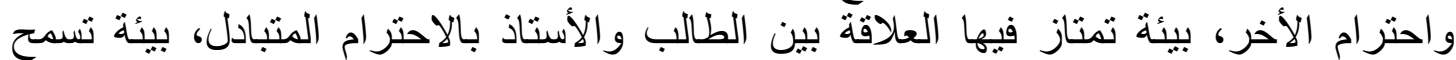

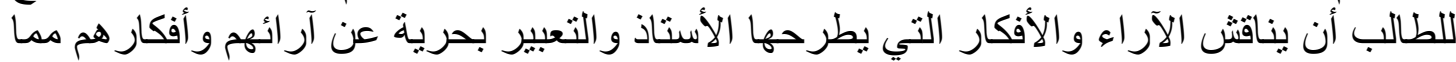

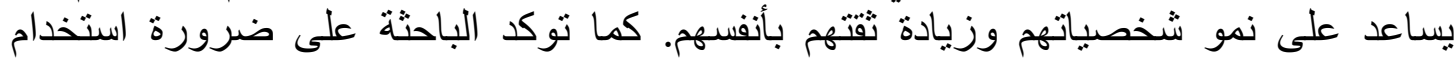
استراتيجيات تعليم وتعلم نشطة متمركزة حول الطالب في تحليل النصوة بانفه الأدبية وربطها

بالقضايا المجتمعية الكلمات الدالة:

المشاركة المدنية ـ تدريس الأدب ـ الصفوف الدرب اسية الديمقر اطية ـ استر اتيجيات التعليم و التعلم النشط 


\section{الملخصات بالانغة العربية}

\section{موقعة ذات كاتبة السبرة الذاتية في الترجمة العربية لنص طعام، صلاة، حب:}

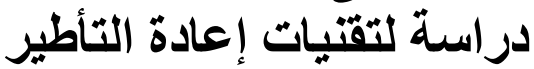

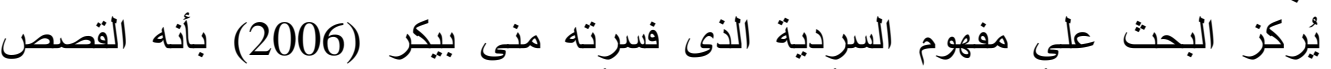

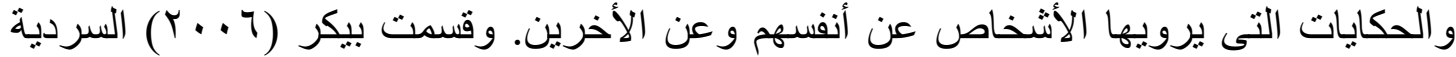

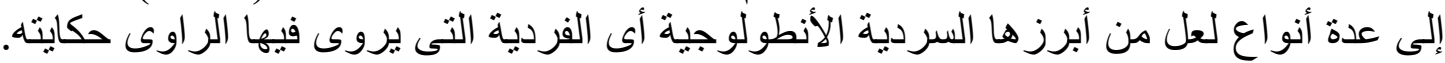

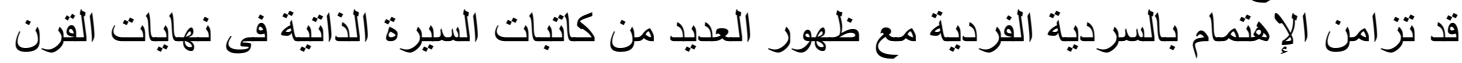
الماضى واللائى قمن بتسجيل حياتهن وخبراتهن فئ في نصوص الته السيرة الذاتية. تتطوى عملية التسجيل تلك على عنصر هام وهو "موقعة الذات" والتى تلى تقوم فيه كاتبة السيرة الذاتية بتحديد

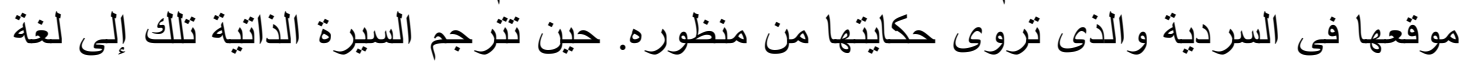

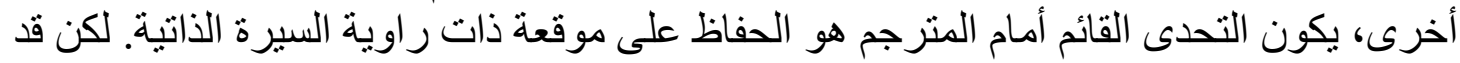

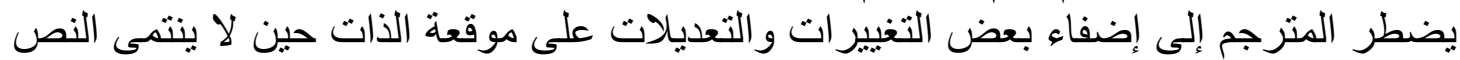

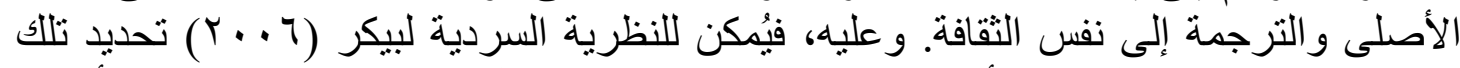

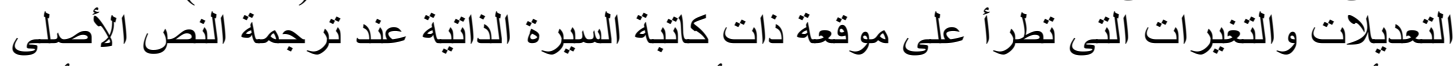

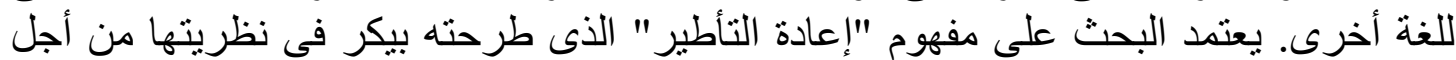

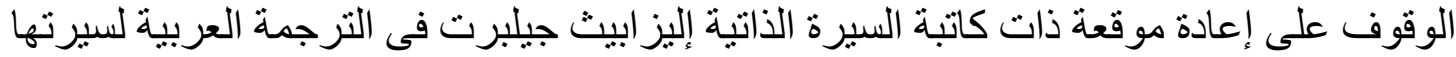

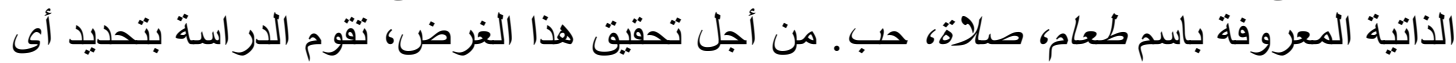

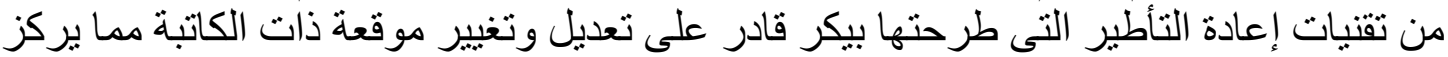

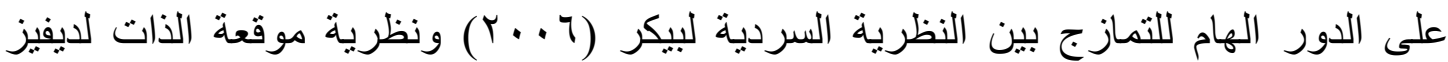
و هارى ( • (199) خاصة أن نوع السردية قد يتغير مع تغير موقعة الذات. 


\title{
الملخصات باللفة العربية
}

\section{المجاز المفاهيمي في القرآن الكريم من منظور إدراكي لغوي}

\author{
دراسة مقدمة من الطالب

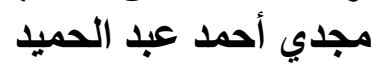 \\ لنيل درجة الدكتوراه من جامعة السويس الجميل \\ تحت إثر اف
}

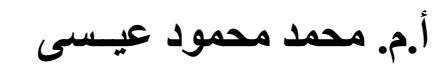

$$
\begin{aligned}
& \text { أستاذ اللغويات بجامعة السويس ميس الِيس } \\
& \text { ورئيس قسم اللغة الإنجليزية }
\end{aligned}
$$

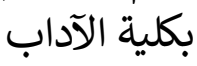

أستاذ اللغويات شاكر رزق تقيّي الدين

مقدمة: البحث:

ويعتبروجود المجاز في في القرآن الكريم ضروري لتوصيل المعنى الذي أر اد الله أن يصل

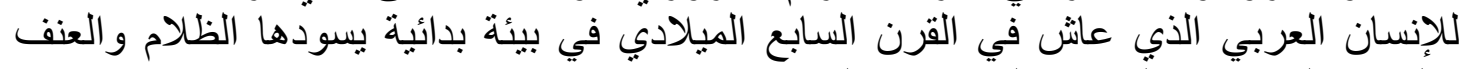

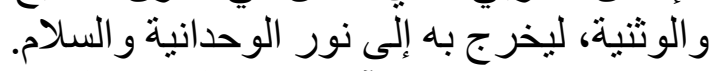

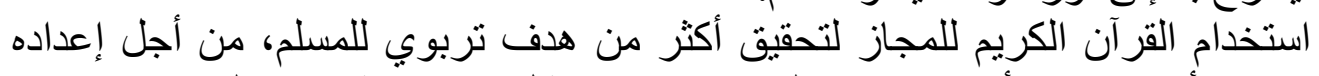

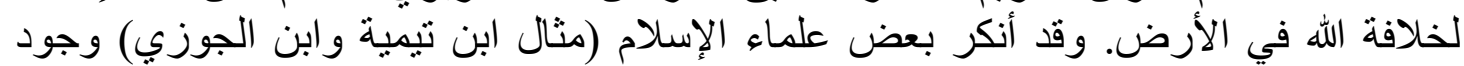

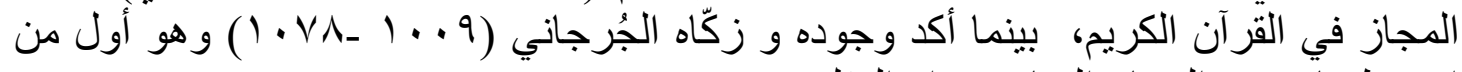

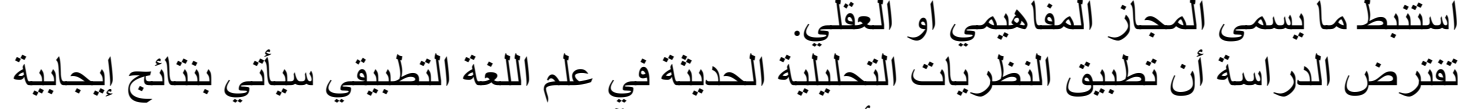
تعتبر إضافة لإستيعاب النظريات وفهم أعمق للنص النص القرآيني. 


\section{الماخصات بالاغة العربية}

\section{القارئ المستهلف: أنماط الاتصال فى قصص كيبلج للاطفال}

تهدف هذه الدراسه لعمل فحص نقدى لاستجابة القارئ من خلال دراسة استجابة الأطفال

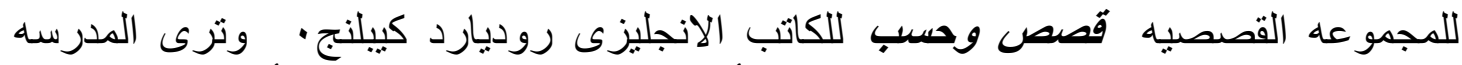

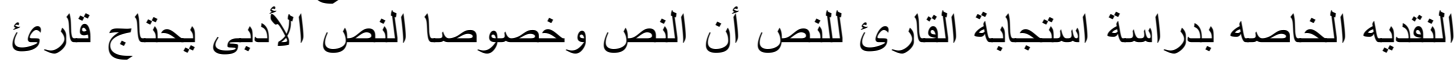

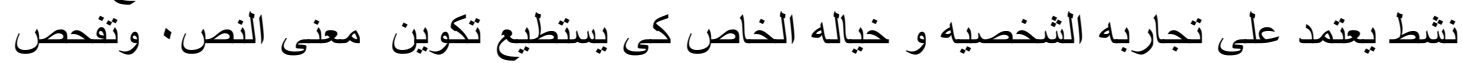

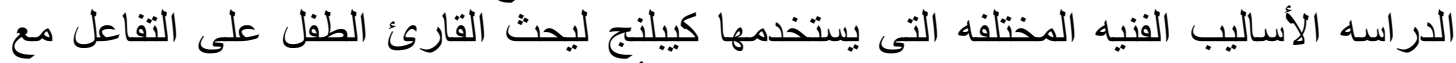

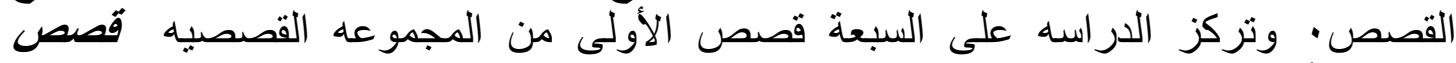
وحسب لأنها جميعا قصص شئر شيقه للحيوان

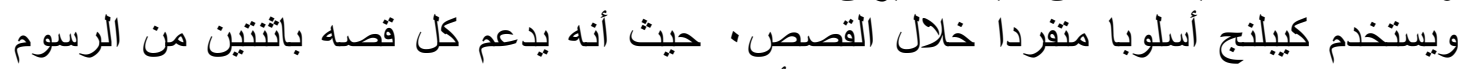

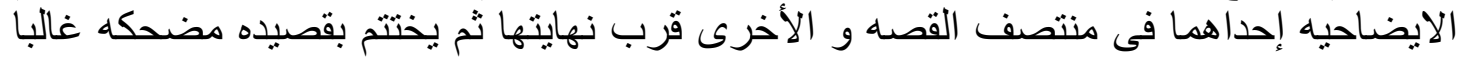

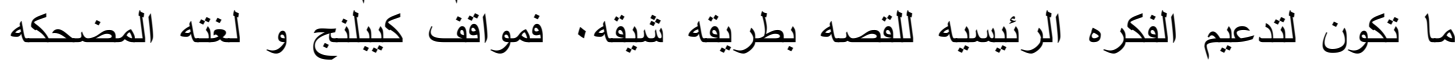

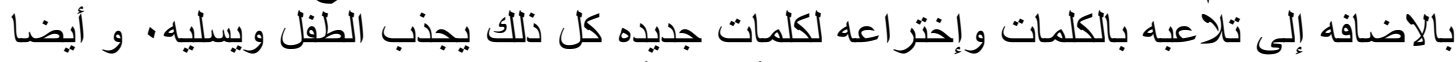

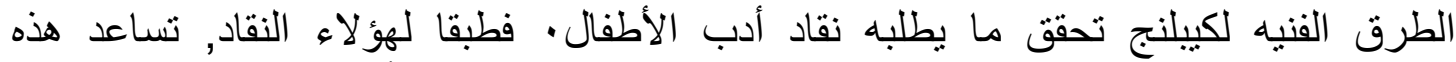

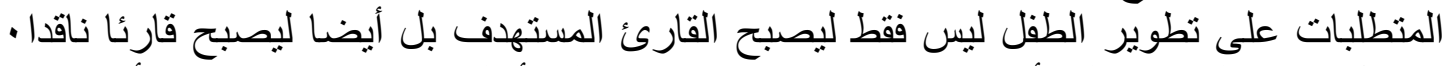

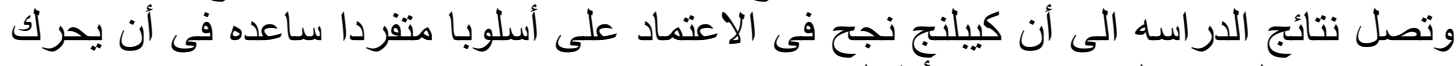
مشاعر وخيال وتفاعل قر ائه من الأطفال. الكلمات المفتاحيه: القارئ المستهدف (المقصود), كيبلنج, أدب الأطفال, النقد الخاص باستجابة القارئ 


\section{الملخصات بالانة العربية}

\section{النجاة من انكار النسب: تحول الإثاريات وتجسيد العاطفة فى رواية سانغيرا}

\section{Shame}

الملخص

تعد كتابة الثهادات من القصص التى "تروى بصيغة المتكلم بواسطة راوِ يكون هو أيضاً بطل

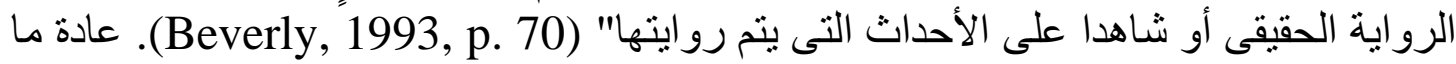

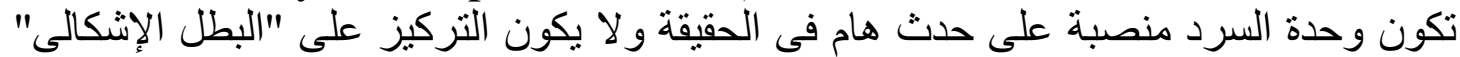

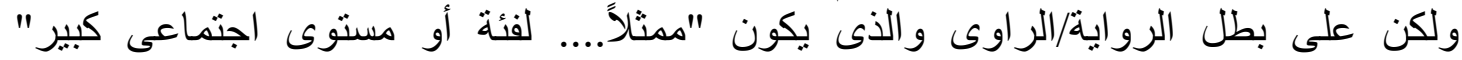
"Beverly, 1993, p. 74)

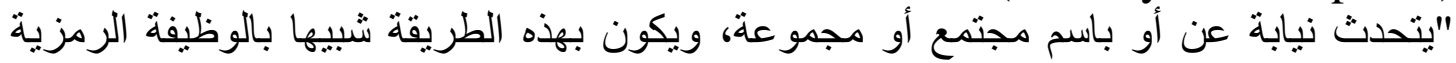

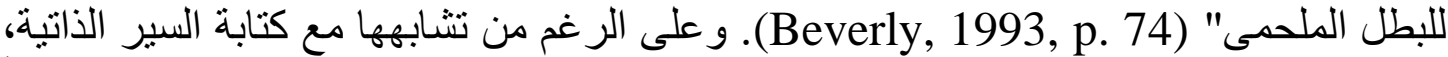

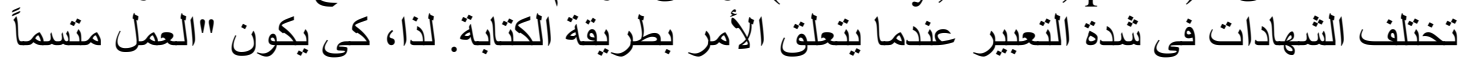

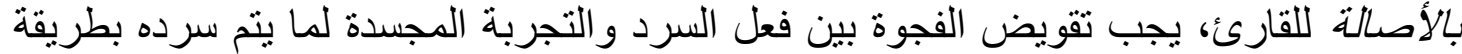

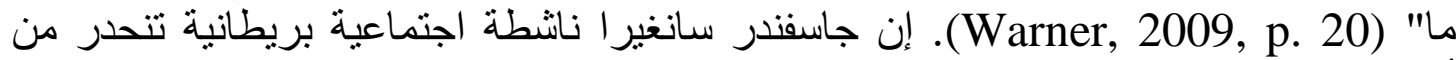

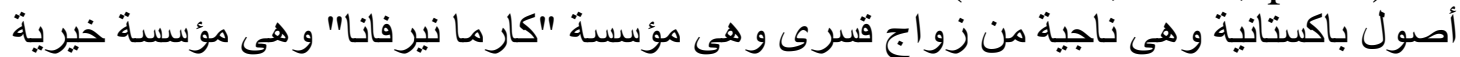

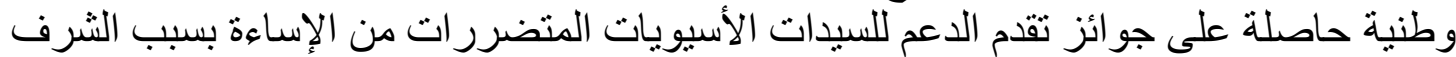

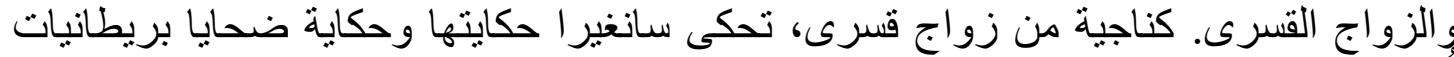

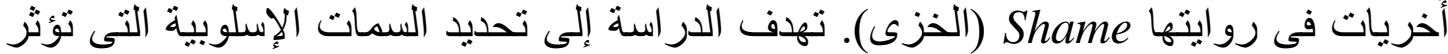

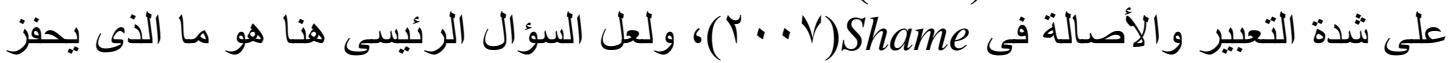

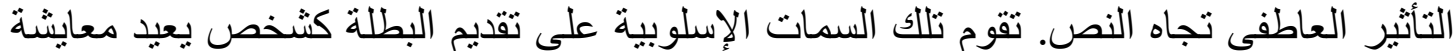

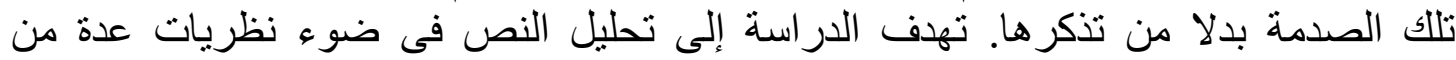

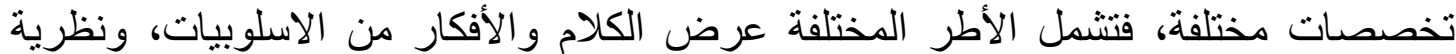

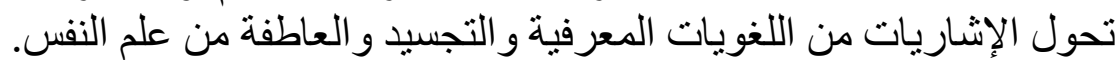

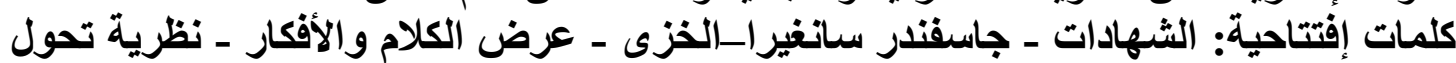
الإشاريات ـ التجسيا والعاطفة الثهات 


\section{الملخصات بالاغة العربية}

\section{الاستعارة المفاهيمية والتصويرية في خطاب مرضى الاكتئاب الرئيس

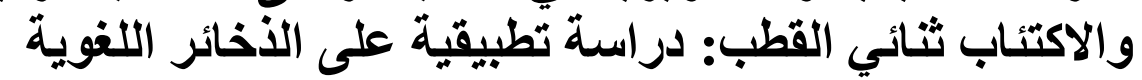

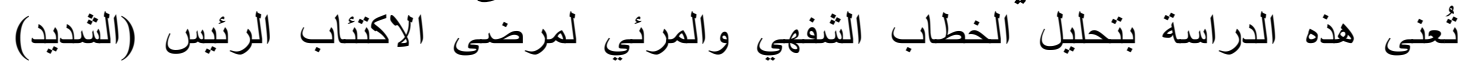
و الاكتئاب ثنائي القطب وذلك لبيان كيف يُشكل المرضى تصور اتهم الإدر اكية والمعرفية عن الترني المرض. وتستخدم الاراسة نظرية الاستعارة المفاهيمية والتي أصدر ها جونسون ولايكوف الإني

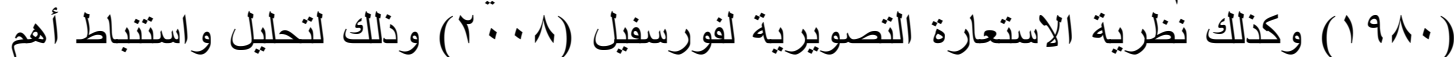
الاستعار ات التي يستخدمها المرضى لتمثيل حالتهم النفسية. ويُعد الاكتئاب حاليا أكثر الأمر اضئه

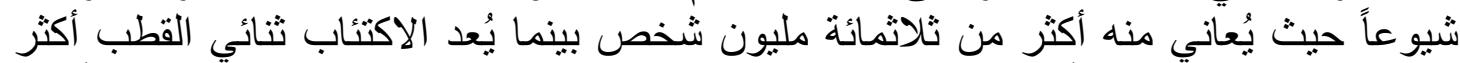

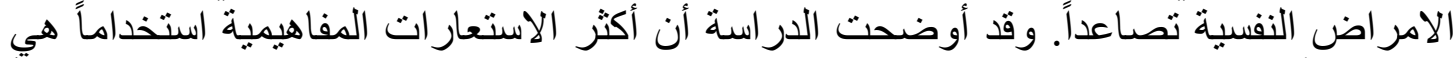

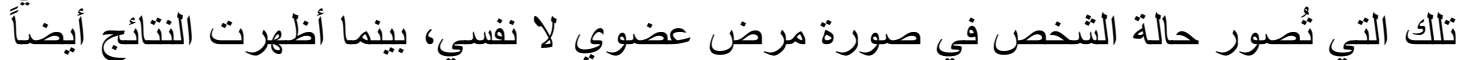

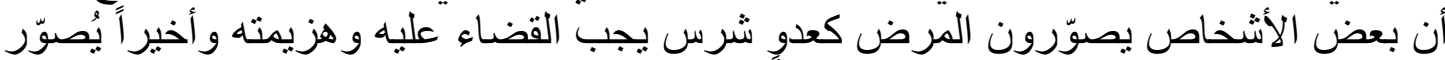

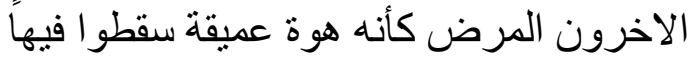

كلمات مفتاحية: الاكتئاب الرئيس، الاكتئاب ثنائي القطب، نظرية الاستعارة المفاهيمية، نظرية

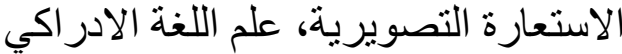




\title{
الملخصات باللفة العربية
}

\section{استخدام المدخل التحرري ( Dogme) في تدريس اللغة الإنجليزية}

لتنميه مهارات التحدث لاي الطلاب المعلمين وكفاعتهم الذاتية في التحدث التهن

اعداد المعبد

\author{
د. هبه مصطفي محمد مصطفي الإنجي \\ أستاذ المناهج و طرق تدريس اللغة الإنجليزية المساعد \\ كليه التربية-جامعه بني سوريف اللغنة الانيزية
}

يتمثل الهذف من البحث الحالي في التحقق من فاعليه المدخل التحرري ( Dogme) في تنميـه

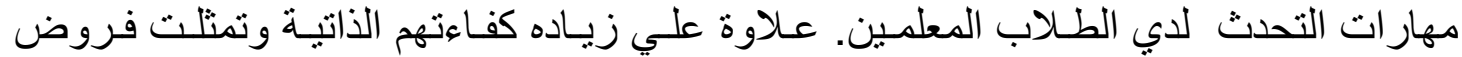

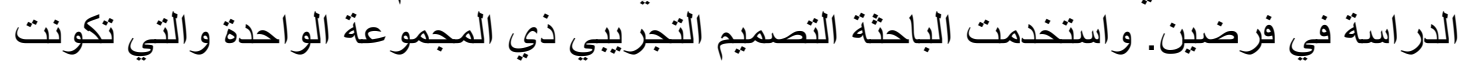

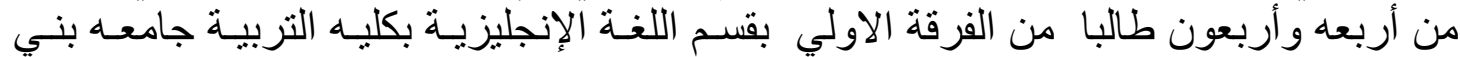

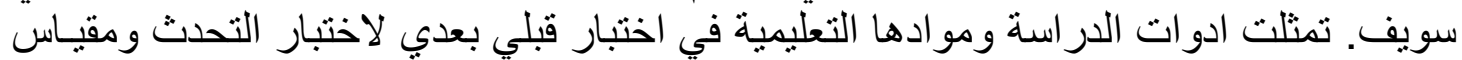

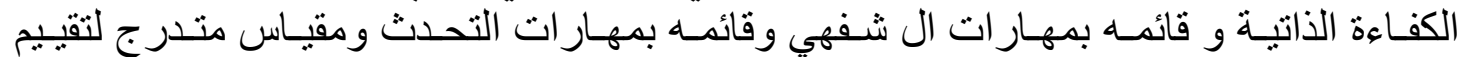

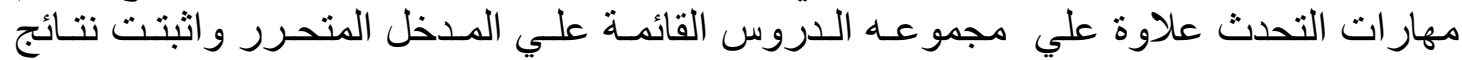

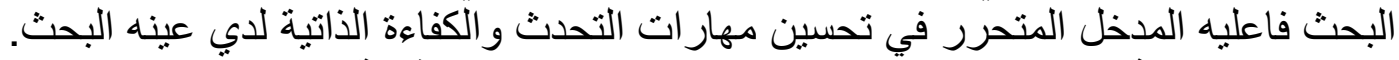
الكلمات المفتاحية: المنهج المتحرر- مهارات التحدثـ الكفاءة الذاتية. 


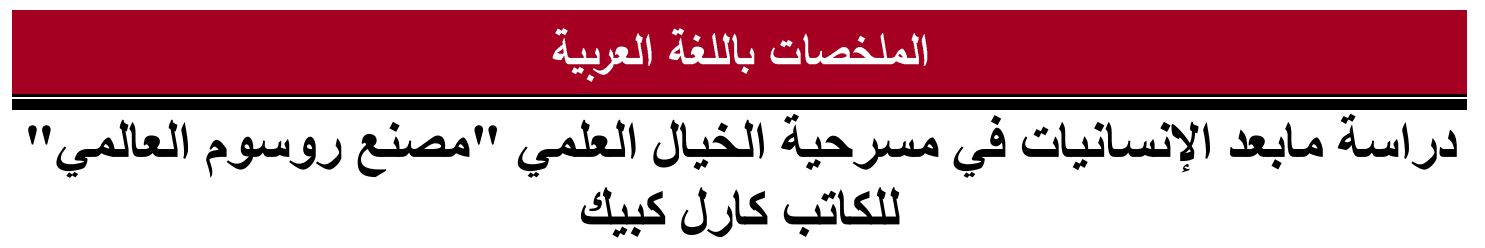

إن الضجة الحالية التي أحدثها الذكاء الإصطناعي من خلال صوفيا الإنسان الآلي (الروبوت)

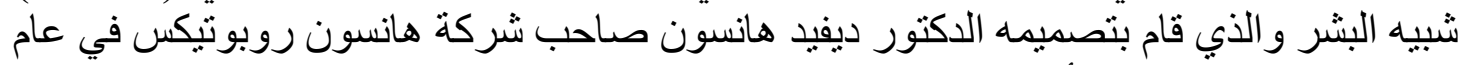

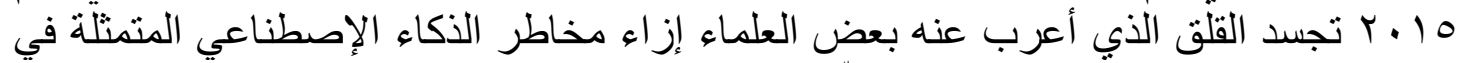

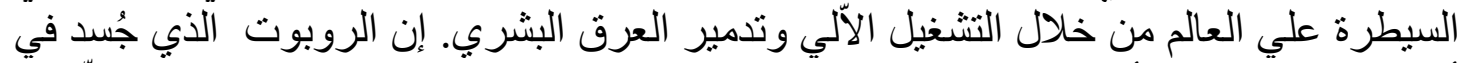

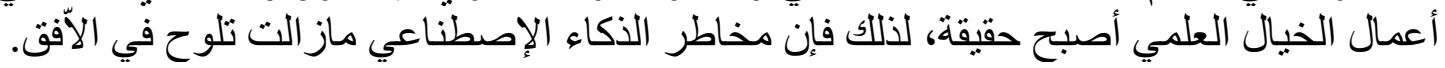

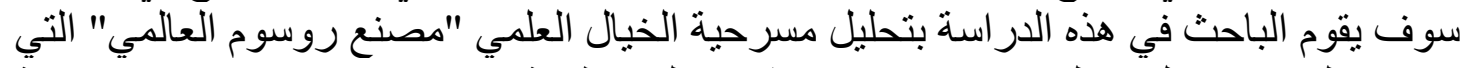

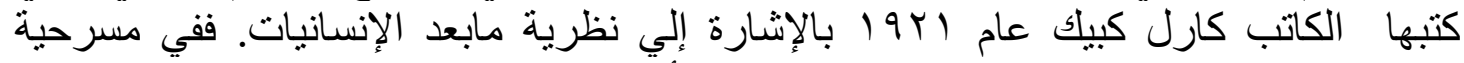

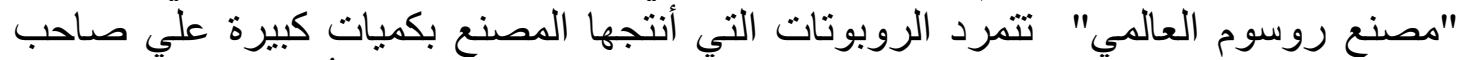

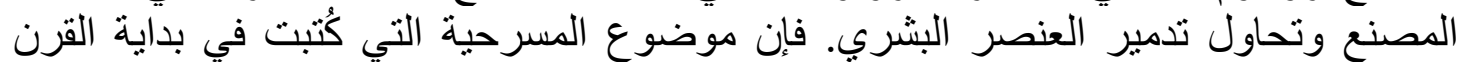

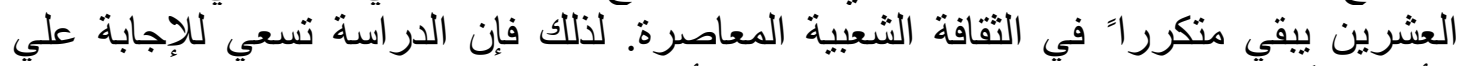

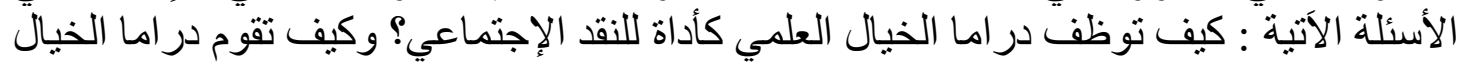

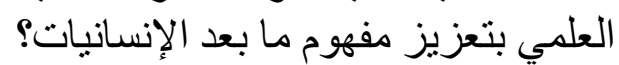




\section{الملخصات بالانة العربية}

\section{حمل العبء إلى النفرلاند: طرد شياطين الغيرية بالتعويذات الشافية للواقعية

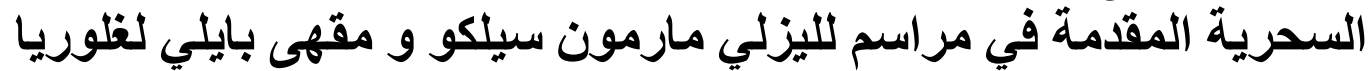

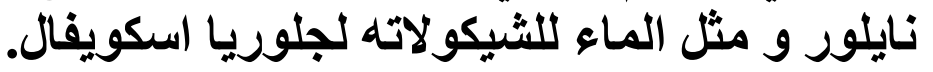 د. رشا محمد وجدى محمد الليثى لآلي}

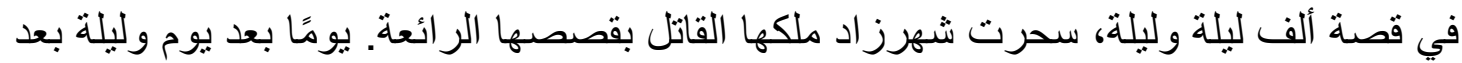

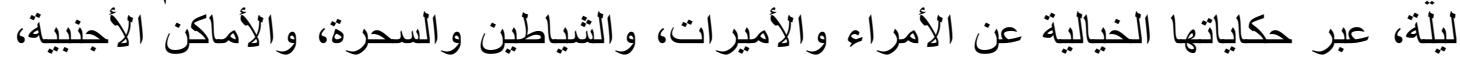

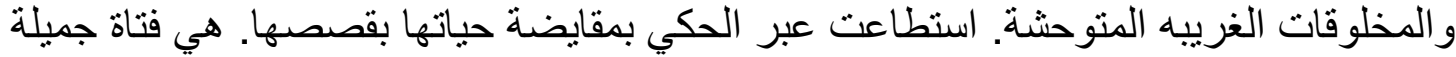

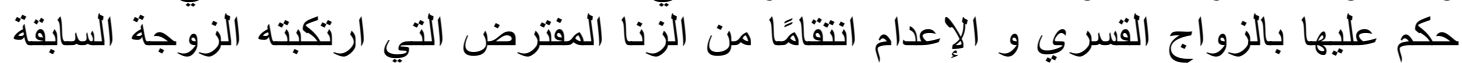

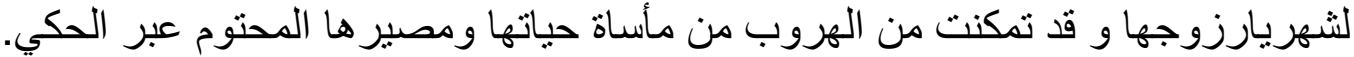

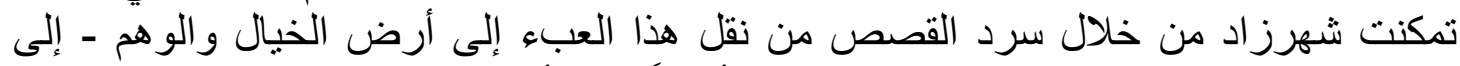

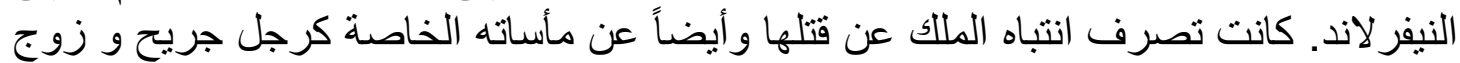

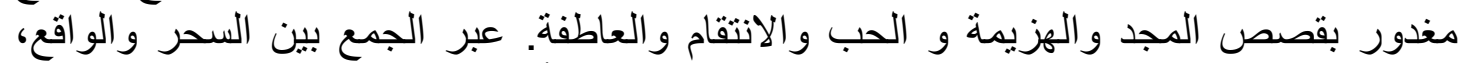

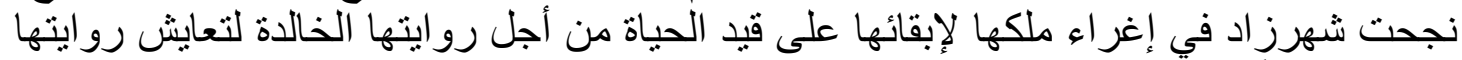

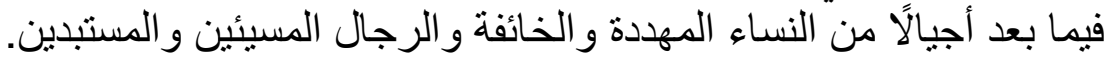

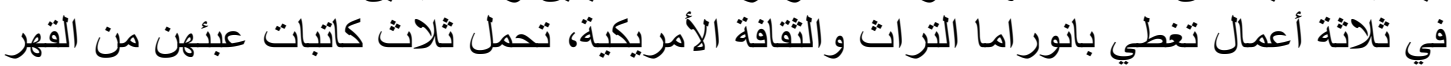

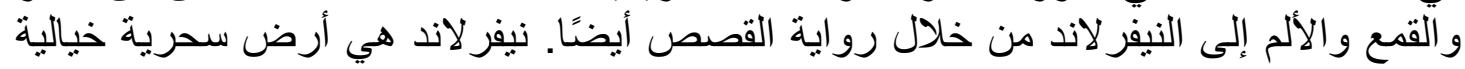

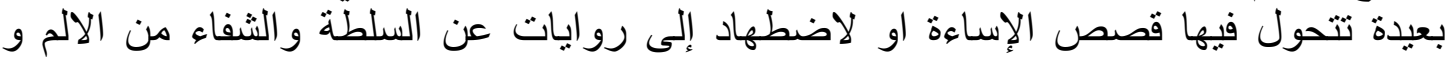

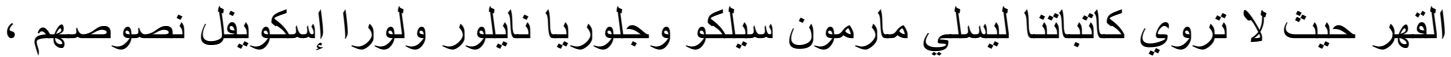

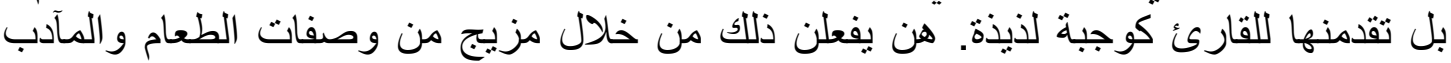

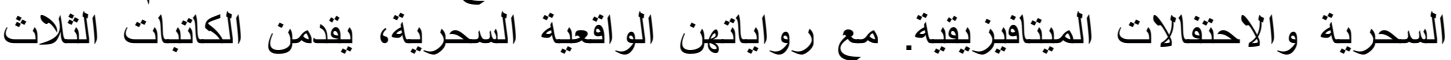

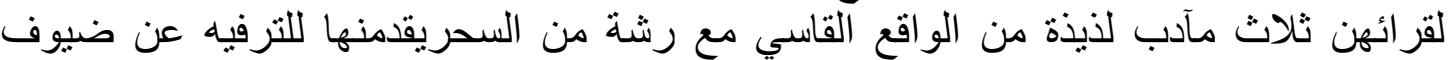

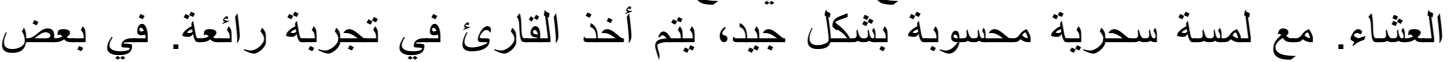

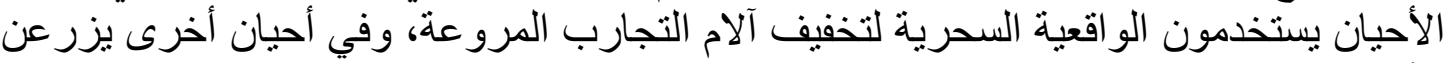
الأمل في حالات ميئوس منها فيقمن بإثر الك القارئ في عملية تطهير هي مزيج بين الإنه تحقيق

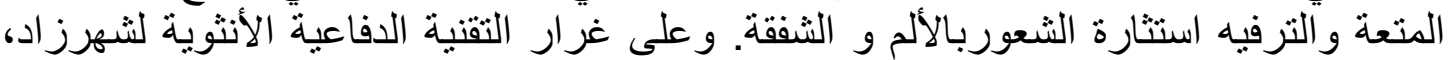

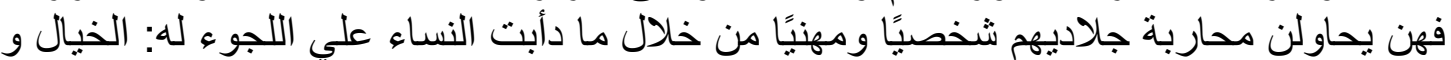

